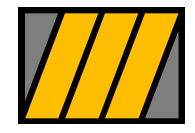

ESCUELA DE NEGOCIOS Universidad Torcuato Di Tella centro de investigación en finanzas

Documento de Trabajo 03/2007

\title{
Zooming in: From Aggregate Volatility to Income Distribution
}

\author{
César Calderón \\ The World Bank
}

Eduardo Levy Yeyati

The World Bank and UTDT

Almirante Sáenz Valiente 1010 C1428BIJ Buenos Aires • Tel: (54 11) 5169.7300

Fax: (54 11) 5169.7347 - Web site: http://www.utdt.edu 


\title{
Zooming In: From Aggregate Volatility to Income Distribution
}

\author{
César Calderón
}

Eduardo Levy Y eyati ${ }^{1}$

\begin{abstract}
In contrast with a growing literature on the drivers of aggregate volatility in developing countries, its consequences in terms of individual incomes have received less attention. This paper looks at the impact of cyclical output fluctuations and extreme output events (crises) on unemployment, poverty and inequality. We find robust evidence that aggregate volatility has a regressive, asymmetric and non linear impact, as reflected in the strong influence of extreme output drops. Our test shows that, in addition to the mitigating role of personal wealth, public expenditure and labor protection exert a similar benign effect. These findings are in line with the income substitutions view of social safety nets, and cast a new light on the value of social programs and labor market regulation in crisis prone developing countries.
\end{abstract}

${ }^{1}$ César Calderón is with The World Bank, Eduardo Levy Y eyati is with Universidad Torcuato Di Tella and The World Bank. The authors want to thank Igor Zuccardi for his invaluable research assistance, and Art Kraay, Norman Loayza, Humberto López and participants at the 2006 World Bank's Pre-conference on Country Insurance, the IMF/ World Bank seminar, and the 2007 LACEA meetings for their useful comments and sugestions. The usual disclaimers apply. 


\section{Introduction}

Perhaps the most distinctive characteristic of developing economies is their macroeconomic volatility. Output growth, exchange rates or current account balances tend to exhibit large and, in many cases, sudden variations, with deleterious and persistent impacts on social welfare. This volatility has been historically attributed to various country-specific factors that range from an excessive dependence on a few goods and services or a narrow tax base, to poor institutional quality and economic policies and, more recently, to a greater exposure to external shocks to commodity prices or global liquidity and risk aversion. ${ }^{2}$ Whatever is its source, a precise understanding of the welfare consequences of macroeconomic volatility needs to go beyond the characterization of aggregate fluctuations.

With the aid of an epidemiological analogy, we can usefully distinguish between three degrees of vulnerability to macroeconomic shocks: (i) the exposure to the pathogen agent (namely, the size and frequency of the shocks); ${ }^{3}$ (ii) the propensity to catch a disease after being exposed (namely, the aggregate sensitivity to the shock as measured, for example, by the output response); and (iii) the resilience of the human body (namely, the consequences of aggregate volatility on individual incomes as captured, for example, by the effect of a sharp output drop on unemployment, school enrollment, poverty and inequality). Ultimately, much in the same way as the effect of a virus on the individual's health reflects the combination of these three degrees, poverty ratios will depend on exposure (e.g., sharp changes in terms of trade), propensity (larger in open economies with rigid prices and limited access to international capital) and resilience (or lack thereof, as in the absence of a social safety net).

The first two degrees have tended to dominate the debate on systemic vulnerability at the expense of the third. In contrast with a vast literature on the drivers of aggregate volatility in

\footnotetext{
2 The new perspective, partially triggered by emerging market crises in the 1990s, has been stressed, among many others, by Calvo (1988) and, more recently, Cole and Kehoe (1996). See also Hausmann and Velasco (2004) for a survey, and G onzalez Rozada and Levy Y eyati (forthcoming) for empirical evidence.

${ }^{3} \mathrm{~A}$ pathogen is a disease causing microorganism or related substance (e.g., a virus) or, more generally, a risk factor or a source of disease.
} 
developing countries, ${ }^{4}$ the impact of the latter in terms of individual incomes has received little attention. The goal of this paper is precisely to characterize this impact and to examine potentially mitigating policies. More specifically, we assess the effects of aggregate volatility and extreme output fluctuations on key microeconomic dimensions such as inequality, poverty, labor income and school enrollment, and investigate the channels and mitigating factors underlying these effects.

While the literature have examined the (bi-directional) link between growth and poverty, ${ }^{5}$ the conventional view that recessions have deleterious effects in terms of social exclusion and human capital losses, particularly persistent and regressive in less developed countries, has received relatively little attention. A few empirical studies on the subject are worth noting. Breen and Garcia-Peñalosa (2005) show that output volatility and income inequality (as captured by the Gini coefficient and the income share of the top quintile) are positively correlated across countries. ${ }^{6}$ Agénor (2004), based on a small 19-country panel, finds an asymmetric effect of real output growth per capita on poverty: deeper recessions tend to raise poverty, whereas faster recoveries do not reduce it in the same degree. Evidence on a positive correlation between output volatility and inequality is also reported by Gavin and Hausmann (1998) and Laursen and Mahajan (2004): in the latter, inflation, financial depth, and government social security expenditures are considered as the suggested channels; in the former, it is the lack of safety nets, that forces low-income children drop out of school in bad times not to return in good times, thereby perpetuating income inequality. While these pieces are often either too fragmentary, based on a limited country sample or subject to methodologically shortcomings - and have therefore failed to make a convincing case in one

\footnotetext{
${ }^{4}$ The literature on output volatility is too vast to summarize here. On the incidence of terms of trade shocks, see Easterly et al. (1997), Fernández Arias et al. (2001), Barro and Sala-i-Martín (2004), Loayza et al. (2005) and Arora and Vamvakidis (2005). On the role of openness on output volatility, see Easterly et al. (2000), Kose et al. (2003), Bekaert et al. (2004) and Cavallo (2005). On the mitigating role of exchange rate flexibility, see Broda (2004), and Edwards and Levy Yeyati (2005) and Ramcharan (2007). Raddatz (2007) provides an encompassing analysis. Of particular interest for our purposes is a recent line of research that looks into the effects of extreme output drops (see, e.g., Becker and Mauro, 2006).

${ }^{5}$ See. i.a., Kraay (2006) and López and Serven (2007) for the impact of poverty on growth, and the latter for the feedback of poverty and inequality on growth.

${ }^{6}$ Checchi and Garcia Peñalosa (2004) also explore the effect of output volatility and economic inequality through the channel of human capital.

7 The same asymmetry is found by De Janvry and Sadoulet (2000) for a panel of 12 Latin A merican countries between 1970 and 1994.
} 
way or the other- López (forthcoming), in a more systematic study, also reports evidence on a positive volatility-inequality link.

Micro studies on the distributive consequences of financial crises largely point in the same direction. Baldacci, de Mello and Inchauste (2002) argue that financial crises are associated with an increase in poverty and, in some cases, income inequality, whereas Corbacho, García-Escribano and Inchauste (2007) find that higher unemployment is a significant source of income vulnerability during a crisis -and, accordingly, they find that households where heads hold more stable public sector jobs are less affected-, and McKenzie (2004) shows that the main distributive impact of a crisis is through a large fall in real wages across the economy owing to weak labor demand. In turn, Halac and Schmukler (2004) document that large (presumably higher-income) depositors were the first to run in the midst of the 2001 Argentina crisis, shifting the burden of the deposit reprogramming and forceful currency conversion disproportionately on smaller (presumably lower-income) savers. Finally, D uncan, Beegle, Frankenberg, Sikokid, Strausse and Teruel (2004) find a permanent drop in school enrollment during a crisis, as more members of a household need to enter the labor force to make up for the declining income of wage earners.

To complement this literature, in this paper we revisit many of these related aspects -and some new ones- from a comprehensive perspective. We use panel regressions to examine empirically the link between aggregate volatility and extreme output fluctuations (including but not limited to financial crises), on the one hand, and income distribution, labor income, poverty and school enrollment, on the other. Additionally, we evaluate potential mitigating factors such as public spending (as a proxy social safety nest) and labor protection. We find that:

- The adverse effect of an economic contraction is not fully undone during the recovery phase. As a result, output volatility is indeed associated with greater inequality, both measured as the GINI coefficient and as the relative income response across income quintiles.

- The volatility-inequality link is non linear and asymmetric: extreme output contractions (but not extreme output expansions) are correlated with inequality beyond what can be explained by standard output volatility measures. 
- The adverse effects of volatility and sharp economic contractions are mitigated by initial per capita income (low income countries are affected the most by macroeconomic volatility) and public expenditure.

- The same pattern (adverse effect of volatility and economic contractions, mitigating influence of public spending) is found for education (school enrollment) and poverty (poverty gap and poverty headcount).

- Labor markets play a key role in the transmission of aggregate volatility to inequality and poverty: labor regulation that increases firing costs attenuates the link, minimum wages amplify it, and the labor-to-capital compensation ratio declines with volatility and output drops.

The plan of the paper is as follows. In section II, we characterize aggregate volatility in terms of measurable variables, and illustrate their incidence across income and development levels. In section III, we estimate the impact of output volatility on inequality and poverty, stressing its non-linear and asymmetric effects: the fact that extreme output contractions (unlike extreme output booms) exert a more than proportional impact. Section IV studies the role of mitigating factors (per capita income, fiscal spending and labor protection) and documents the effect of volatility on school enrollment. Finally, section V summarizes the findings of the paper, and concludes.

\section{The starting point: Aggregate volatility}

The first step in our explorations is the characterization of aggregate volatility. For this, we deviate from the standard growth literature only slightly. We use three measures for output volatility: the standard deviation of log per capita output, of Baxter and King's band-pass filtered log output, and of output detrended by a quadratic trend. In addition to the cyclical variability of output, we use two measures of extreme output events, namely, sharp output drops that go the beyond the order of cyclical contractions, and that are typically associated with economic crises: a 5\% cumulative decline in output relative to its level prior to the decline, and a Current Depth of Recession (CDR) variable that measures the difference between the current GDP and the last local GD P maximum. 
For reasons that are discussed in the next section, our prior is that aggregate volatility has asymmetric, non linear effects: a sharp contraction exerts a more than proportional influence on employment, poverty and inequality - that a sharp expansion does not undo completely. In order to identify these nonlinearities and asymmetries, good precise measures of aggregate volatility are critical. We focus on the post-Bretton Woods era (1975-2005).

\section{a. First glanœ}

Figures 1 characterizes aggregate volatility for different income (high, middle, low) and development (industrial, non-industrial) categories. ${ }^{8}$ As can be seen, output volatility in developing countries (as measured by the standard deviation of real growth rate over the period 1975-2005) almost triples that for the developed group. Similarly, high income countries enjoy greater stability than low- and middle-income economies, even after excluding small countries which are likely less diversified and more sensitive to external real shocks.

The same picture is obtained when we look at extreme output events, measured in this case as a 5\% cumulative decline in output relative to its level prior to the decline. Again, the propensity to suffer sharp output contractions in non-industrial economies is many times larger than in the industrial world, suggesting that the greater output volatility may reflect the incidence of these extreme downturns.

\section{The ultimate toll: From aggregate volatility to income distribution}

A critical - and often overlooked- degree of vulnerability concerns the capacity of countries in general, and developing ones in particular, to forestall the negative welfare consequences of the adverse swings in economic activity documented in Figure 1 Higher exposure to exogenously-triggered output contractions or financial disarray does not imply, per se, larger

\footnotetext{
${ }^{8}$ Categories are drawn from the World Bank's classfication. The middle-income sample include both low- and high-middle income countries. Variable definitions and sources as well as summary statistcs for all the relevant variables in the paper are reported in the Appendix.
} 
income or distributive effects. Alternatively, similar output contractions would tend to affect some countries (typically, rich countries where the fraction of low-income population with no savings is smaller and is largely covered by a well-deployed social safety net) more than others (typically, low-income countries where the majority of the population tends to live on their current income).

Moreover, the fact that economic contractions reduce current consumption does not necessarily mean that aggregate volatility (namely, a succession of contractions and expansion) translates into poorer welfare indicators over the long haul. For that to be true, one needs to show, at least, that the recovery phase does not fully undo the deterioration over the recessive phase.

In this section, we document the negative effect of output volatility and output drops on measures of inequality and poverty, and report evidence on the presence of persistent effects of recessions underlying this negative link. To do that, we run 5-year non-overlapping panel regressions for a number of alternative measures of output volatility, and test for asymmetric effects by controlling separately for output drops and output jumps (where the latter are defined as the mirror image of drops).

\section{a. D istributiveimpact of output volatility}

The preliminary message from a panel regression of income distribution (as measured by the GINI coefficient) on aggregate output volatility (measured as the standard deviation of per capita GDP) is clear: volatility increases inequality (Table 1). ${ }^{9}$ The findings are comparable irrespective of the methodology: the table reports results using fixed-effect panel regressions, Arellano and Bond's (1991) GMM difference estimator, and Blundell and Bond's (1998) GMM system estimator using internal or external instruments. ${ }^{10}$

\footnotetext{
9 Distribution data is particularly difficult to compare across countries because they are often based on different measures of welfare and income, and different units of observation (D ollar and Kraay, 2002; D eaton, 2004); hence the statistical advantage of panel regressions to control for these country-specific measurement methodologies.

${ }^{10}$ Since the results are robust to methodology, for conciseness the remaining tables report results using GMM with the following external instruments for output volatility: volatility of terms of trade shocks volatility of
} 
The baseline specification includes, in addition to the lagged dependent variable, standard growth controls such as human capital (proxied by secondary school enrollment), initial income (linear and squared to capture non-linearities), plus the inflation rate (another indicator of economic malaise positively correlated with both output volatility and inequality) and public expenditure (current government expenditure over GDP) to proxy for social programs, which we expect to be negatively associated with poverty and inequality. All of them, when significant, display the expected sign.

In addition, the last two columns of the table replicate the specifications in columns 3 and 4 for the subsample of developing countries. The association, if anything, is stronger, dispelling doubts that the result may be driven by differences between developed and developing economies - and hinting at the degree of development as a factor influencing behind the volatility-inequality result.

Alternative measures of output volatility (using Baxter and King's band-pass filter, or a quadratic trend) confirm these findings (T able 2). Similarly, the findings are not specific to the GINI coefficient: replicating the exercise for the share of the income of the average household in each quintiles of the income distribution over total income tells a consistent story: volatility increases the income share of the upper quintiles at the expense of the lower ones (Table 3; column 4 of Table 1 is reproduced for ease of comparison). Moreover, the effect is monotonic, increasing with each subsequent quintile. Figure 2 illustrates the economic importance of these findings: based on the estimates reported in Table $\mathbf{3}$ a doubling in aggregate volatility leads to an $2.7 \%$ increase in the Gini coefficient, a $2.4 \%$ decline (1.1\% increase) in the income share of the poorest (richest) quintile.

\section{b. D istributive hysteresis and the persistent effect of recessions}

The previous findings document the negative link between aggregate volatility, on the one hand, and inequality, on the other, but are silent about two aspects that are critical to 
characterize the welfare consequences of aggregate fluctuations: (i) non-linearities (in particular, the distinction between standard cyclical volatility and presumably more damaging extreme output events), and (ii) asymmetries (the fact that the losses due to sharp recessions are not perfectly recouped during the ensuing expansion, a pattern that would explain the association between volatility and inequality over the long run).

As in the previous section, to explore the incidence of extreme negative output events, we use two alternative definition of an output event: output drops (defined as recessions with a cumulative output loss in excess of 5\%) and current depth of recession (CDR, defined as recessions with a maximum output decline in excess of 3\%) where the decline is computed in both cases relative to the GDP at the beginning of the recession. In the regressions, the negative output event dummy takes a value of one if the event takes place (or starts) within the current 5-year period. In addition, we control for positive output events using the mirror image of the output drop and depth of recession dummies, denoted accordingly as output jumps and current depth of boom.

The results, reported in Table $\mathbf{4}$, are encouraging. Once extreme events are controlled for, the coefficients for volatility decline substantially but still exerts a significant influence; by contrast, extreme output expansions do not appear to play any significant role beyond what is already captured by the output volatility variable. This indicates that the greater propensity to suffer extreme contractions characteristic of developing economies adds to the deleterious

effect of regular business cycles on inequality. Moreover, the results suggests that extreme events do not exert e symmetric influence: the increase in inequality after a drop is not reverted during the subsequent boom. Figure 3 illustrates the economic size of the effect: Based on the estimates in column 3 of Table $\mathbf{4}$ we find that an output drop raises the Gini coefficient a sizeable $5 \%$, compared with a meager (and not statistically significant) $0.9 \%$ as a result of a jump.

\section{Mitigating factors}

There a number of ways in which countries can mitigate the micro impact of macro volatility. Individually, agents could insure against such events by saving in good times (both 
domestically and abroad) or purchasing insurance against easily verifiable catastrophic events. Collectively, the government can (and often does) offer social safety nets that alleviate the income effects of uninsured negative shocks. For example, the impact of a sharp economic contraction could be softened by the holding of real assets, or by the countercyclical public expenditure in social assistance to low income households with no savings. If so, it would follow that the income effect of an output drop would tend to be milder in countries with larger public expenditure or greater access to (and use of) saving instruments.

More generally, a tenet of standard economics is the fact that savings help smooth out output fluctuations, so that output volatility should not (fully) translate into consumption volatility. However, it is well known that savings among low- and middle-income households tend to be, at best, limited -and that access to finance in times of trouble is virtually inexistent. Moreover, significant output drops typically involve not simply wage cuts but very often a sharp increase in unemployment. Finally, there is a large share of the population out of the labor force (most notably, the aged) that obtain their current income from social security benefits, pensions and social programs publicly imperfectly indexed income that may be easily diluted in the context of an inflationary crisis. For all these reasons, the consequences of output volatility on income distribution could in principle be alleviated by savings (which, in turn, would depend on the household's income that determines its savings ratio). On the other hand, for low-income households with no savings, income volatility could be smoothed out by non-labor income such as unemployment insurance, social safety nets or social security outlays.

D oes the level of per capital income reduce the adverse consequences of aggregate volatility on income distribution? D oes the presence of social safety nets mitigate the effect of output fluctuations on the lower quintiles? We examine each of these questions in Table 5.

We first look at per capita income, more precisely at the interaction of initial income with our volatility proxy (column 1). The results strongly suggest that income matters for resilience: the poorer the country, the more harmful volatility is in terms of income distribution, particularly for the lower quintile. We turn next to the role of social 
expenditure, proxied by public sector current expenditure over GDP (column 2). The results, consistently support our priors: public expenditure appears to have a progressive effect on income distribution.

Per capita income and public expenditure tend to be highly correlated. Moreover, to the extent that per capital income may be simply the reflection of economic development that usually entails a larger public sector, the findings may lead to the rather unsurprising -and policy-irrelevant- corollary that the richer the country, the better equipped it is to cope with aggregate volatility. Column 3 dispels these doubts: when put together, both income and public spending retain their explanatory power (if anything, the coefficients increase slightly). Moreover, the same applies to income shares (columns 4 to 8) where both interactions are in almost all cases significant and consistent with our priors. In particular, the results indicate that policy aspects (such as social spending) do have a bearing on the ultimate effect of aggregate volatility beyond the country's level of economic development, shifting the burden of aggregate volatility toward the upper income levels. ${ }^{11}$ Figure 4 illustrates the economic importance of these findings, both for the $\mathrm{G}$ ini coefficient and the income shares.

As already noted, volatility may not be the appropriate metric to measure the effects documented in the previous tables. More precisely, much in the same way as booms and busts tend to have asymmetric and non-linear effects on employment and income - with the consequences of large protracted recessions are likely to be proportionally more important and persistent than traditional business cycle fluctuations- in principle one could expect the same pattern from the mitigating factor.

Indeed, as shown in Table 6, output drops elicit an additional negative effect on inequality. Moreover, whereas public spending buffers both the effect from volatility and from extreme

11 We also looked at financial depth (measured as private credit over GDP) as a proxy for the provision of saving instruments in good times and credit in bad times, another potential mitigating factor. Interestingly, financial depth proved to have the opposite effect: it was positively related to inequality and, when significant, augmented the negative impact of aggregate volatility. In principle, this disappointing result is hardly surprising: because users of financial instruments typically (and, in developing economies, almost exclusively) belong to the upper income classes, a deeper financial system should in principle benefit the rich relative to the poor. By contrast, it can be shown that access to financial services (as measured by branch or ATM penetration), both improves income distribution and mitigates the effect of aggregate volatility (see Calderón and Levy Yeyati, 2007). 
output events, this effect is larger and more consistently significant for the latter. Figure 5 illustrate the economic importance of these effects: for example, the lower quintile may see the impact of a crisis on its income share go from a 5\% loss (in the context of low public spending, defined as the $25^{\text {th }}$ percentile value of public spending in our sample) to a $5 \%$ gain (high public spending, (defined as the $75^{\text {th }}$ percentile value). These findings are in line with the conventional view that social safety nets are most needed in economic crisis, where the low-income strata are hit by high unemployment and low real wages. It is this labor market channel that we explore in more detail next.

a. A nother look at income distribution: labor mark ets in volatile environments

Labor income is possibly the main candidate to explain the previous findings, and a key channel to account for the volatility-distribution link. Unemployment is typically the single most important explanatory factor of the deterioration of income distribution after extreme output contractions. Moreover, it is well known that unemployment increases and wages decrease during recessions, and that long spells of unemployment may entail permanent losses of human capital, downgrading qualified workers to unskilled jobs and ultimately excluding them from labor markets.

In this light, one would expect that labor safety nets that mitigate the effect of sharp economic downturns on unemployment - at the expense of lower employment rates in good times- should also mitigate their effect on equity. Conversely, factors that inhibit price adjustment at the expense of quantity adjustment should have a detrimental influence on equity in the event of a negative shock. The underlying rationale is simple: in the event of an economic recession, a wage cut distributes the burden of adjustment among workers more evenly than a payroll cut. Policies that deter layoffs (e.g., by increasing firing costs) should then improve income distribution; policies that foster layoffs (e.g., minimum wages that limit wage cuts) should worsen it.

With this in mind, we test the incidence of two key characteristics of the labor market on the distributive impact of output fluctuations, namely, minimum wages (specifically, the ratio of minimum wages to manufacturing labor costs), and firing deterrents, which we measure in 
two ways: difficulty of firing (the difficulty and expense of firing a redundant worker) ${ }^{12}$ and firing costs (the cost of a redundant worker, expressed in weeks of wages). The first one, by reducing the margin for wage adjustment, should increase the sensitivity of unemployment to aggregate volatility; the other two should have exactly the opposite effect, reducing unemployment in bad times at the expense of employment in good times.

The results, reported in Table 7, are perfectly consistent with our priors. Whereas minimum wages amplify the consequences of a contraction, the other two variables tend to attenuate its impact. Moreover, as Figure 6 shows, these effects are economically important. Thus, labor market protection aimed at reducing the cyclical labor turnover, while it certainly may introduce other inefficiencies, does insure the worker against aggregate fluctuations.

These findings confirm the relevance of the labor channel to explain the volatilitydistribution link, and suggest an alternative way to approach the distributive effects of aggregate volatility: if economic contractions are associated with a combination of increased unemployment and lower real wages, we should observe a concomitant decline in the ratio of labor to non-labor income.

The question of the distribution of the burden of an economic downturn was a popular policy issue in developing countries all though the 90s -the presumption being that lowmiddle income households with little savings (if any) in unsophisticated financial or illiquid durables goods were ill-prepared to withstand the wealth effect of the typical devaluation and inflation that accompanied the crises. A different but no less relevant question concerned the distribution of the post-crisis recovery effort across different income levels. Edwards (1989) addressed this question empirically by studying the impact of a number of balance of payment crisis events on the participation of labor income in total output, and found no evidence supporting the conventional view that labor tended to bear a

\footnotetext{
12 The index combines 8 components: (i) whether redundancy is disallowed as a basis for terminating workers; (ii) whether the employer needs to notify a third party (such as a government agency) to terminate 1 redundant worker; (iii) whether the employer needs to notify a third party to terminate a group of 25 redundant workers; (iv) whether the employer needs approval from a third party to terminate 1 redundant worker; (v) whether the employer needs approval from a third party to terminate a group of 25 redundant workers; (vi) whether the law requires the employer to consider reassignment or retraining options before redundancy termination; (vii) whether priority rules apply for redundancies; and (viii) whether priority rules apply for reemployment.
} 
disproportionate share of the burden. On the other hand, while less directly related to sharp economic downturns, recent work by Levy Y eyati and Sturzenegger (2007) document the association between an undervalued local currency - typical of a post-crisis scenario- and a lower labor to capital compensation ratio.

The question is naturally linked to our exploration: to the extent that the share of labor to non-labor income is negatively correlated with total income (a logical implication of the lower endowments and saving propensity of the poor), one would expect that a decline in the ratio of labor to capital income in countries that have gone through volatile periods and deep recessions would translate in a deterioration of the distribution of income.

This is precisely what we examine in Table 8 where the ratio of capital to labor compensation is regressed following our baseline specification, and controlling for output volatility, extreme output events, and their interactions with public expenditure and labor market rigidities. In line with our previous findings, the ratio increases with volatility and (more strongly) with output events, and the effect is partially muted by public spending and difficulty of firing. ${ }^{13}$ In sum, the response of labor income appears to be a decisive (if not the main) factor in explaining the adverse distributive effects of aggregate volatility.

\section{b. Education}

In a recent paper, Thomas et al. (2004) find that, during the 1998 Indonesian crisis, household spending on education, as well as school enrollment, declined more for poorer households. While we cannot replicate these tests for a broader set of countries (due to lack of data on spending and enrollment per household income level), we can document the broader negative effect of economic contractions on education, as Table 9 clearly shows. Moreover, again, we find that public spending plays a compensating role, much in the same way as an implicit subsidy to investment in education. Figure 7 further illustrates the effects: going from low to high public spending (defined as before as the $25^{\text {th }}$ and $75^{\text {th }}$ percentile

\footnotetext{
${ }^{13}$ While the volatility coefficient is barely or not significant once extreme events are controlled for, the
} coefficient declines only slightly. 
values in our sample) halves the negative effect of volatility on school enrollment (from $10 \%$ to $-5 \%)$, and dramatically reverts the impact of extreme output events.

\section{c. Poverty}

The evidence that income shares tend to move in a regressive way as volatility increases does not, per se, imply that low income households are worse off in absolute terms in volatile economies. More precisely: Is the evidence reported above the reflection of a situation in which the rich gains at the expense of the poor in a zero (or negative) sum game, or is it the case that rich people can profit from a volatile but growing environment, at no cost in terms of the income of the lower quintiles? In other words, does the effects of income distribution reported above translate into a deterioration of the poverty indicators?

Table $\mathbf{D}$ provides a positive answer to that question. The table shows estimates of a regression of per capita income growth for the bottom quintile to examine the absolute effect of aggregate fluctuations on income of the poor. The tests, which are similar to those used above for income distribution, reveal a systematically negative effect of alternative measures of volatility on poor households. Again as before, public expenditure appears to play a mitigating role, a result robust to alternative versions of the volatility variable.

A consistent story arises when we use a measure of the poverty gap and a poverty headcount index, ${ }^{14}$ where the negative effect of volatility is alleviated by public expenditure. O nce again, extreme adverse output events place an additional burden on poverty, beyond the effect of cyclical fluctuations, confirming the importance of non-linear effects. The effects, as Figure 8 shows, are economically important, particularly in the face of extreme output declines, when public spending may sharply what would otherwise be a dramatic increase in poverty). Overall, these results complete a remarkably consistent picture of the undesired welfare effects of aggregate volatility, and the benign influence of safety nets.

\footnotetext{
14 Poverty gap ratio is the mean distance separating the population from the poverty line of PPP-adjusted \$1 per day (with the non-poor being given a distance of zero), expressed as a percentage of the poverty line. The poverty headcount index is the share of the population with income below the poverty line. All these formulas are calculated based on data on individual income. If household-level data are used, the formulas are adjusted by the household size times sampling expansion factor for every household i.
} 


\section{Taking stock}

Developing countries are often (and correctly) characterized by their relatively larger aggregate volatility. This concept, however, conflates at least three different degrees of vulnerability that contribute to the ultimate effect of volatility on individual incomes: the exposure to shocks, the aggregate economy response to the shock, and the resilience of individuals within the economy in the face of aggregate fluctuations, which ultimately determines the toll imposed by the aggregate malaise on the individuals' well-being. The vulnerability of developing countries to external shocks compounds the effects of these three degrees, a distinction that is crucial from the perspective of policy design.

In this paper, we documented the third degree of vulnerability that goes from aggregate volatility to income distribution: we showed that volatility and, particularly, adverse extreme output events (e.g., macroeconomic crises) have negative and persistent effects on equity and poverty, as well as a discouraging effect on school enrollment. More importantly, we showed that these undesired consequences of volatility and negative income shocks vary substantially as a function of country characteristics: specifically, factors such as per capita income, public spending, or labor protection tend to attenuate the individual cost of business cycles and sharp recessions.

These findings offer a number of important policy implications. On the one hand, the fact that the first two mitigating factors (per capita income and public spending) tend to be correlated with economic development a priori indicates that the welfare effects of aggregate volatility -and, as a result, the benefits of policies or instruments aimed at reducing macroeconomic fluctuations- are more pronounced in developing countries. On the other hand, the benign effect of labor protection (as opposed to income protection such as minimum wages), combined with relative decline in labor compensation associated with aggregate volatility, highlights the insurance benefits of labor regulations, an aspect often downplayed relative to their efficiency costs. Third, on a more speculative basis, it hints at an

alternative explanatory channel for the connection between output volatility and output 
growth documented in the economic literature: ${ }^{15}$ the persistent human capital losses (through protracted unemployment and reduced school enrollment) caused by economic contractions.

${ }^{15}$ See, e.g., Ramey and Ramey (1995) and, more recently, Kose, Prasad, and Terrones (2005) and references therein. 


\section{References}

Agénor, P.R., 2004. "Macroeconomic Adjustment and the Poor: Analytical Issues and CrossCountry Evidence," Journal of E conomic Surveys 18(3), 351-408.

Arellano, M. and S. Bond, 1991. "Some Tests of Specification for Panel Data: Monte Carlo Evidence and an Application to Employment Equations," Review of E conomic Studies 58(2), 277-297.

Arellano, M., and O. Bover, 1995. "Another Look at the Instrumental Variable Estimation of Error-Components Models," Journal of E conometrics 68(1), 29-51.

Arora, V., and A. Vamvakidis, 2005. "How much do Trading Partners matter for Economic Growth?" IM F Staff Papers 52 , 24-40.

Baldacci, E., L. de Mello, and G. Inchauste. 2002. Financial Crises, Poverty, and Income Distribution. IMF Working Paper WP/ 02/ 4.

Barro, R.J., and X. Sala-i-Martin, 2004. E conomic G rowth. McG raw-Hill, Second Edition.

Becker, T.I., and P. Mauro, 2006. "Output Drops and the Shocks that Matter," IMF Working Paper WP/ 06/ 172.

Bekaert, G., H. Campbell, and C. Lundblad, 2004. "Growth Volatility and Financial Liberalization," NBER Working Paper No. 10560.

Blundell, R. and S. Bond, 1998. "Initial Conditions and Moment Restrictions in Dynamic Panel D ata Models," Journal of E conometrics 87(1), 115-143.

Breen, R. and C. García-Peñalosa, 2005. "Income Inequality and Macroeconomic Volatility: An Empirical Investigation," Review of D evelopment E conomics 9(3), 380-398.

Broda, C., 2004. "Terms of Trade and Exchange Rate Regimes in D eveloping Countries," Journal of International E onomics 63(1), 31-58.

Calderón, C. and E. Levy Y eyati, 2007. "Finance and the Poor: What Matters and What D oesn't?," The World Bank, manuscript

Calvo, G., 1988, "Servicing the Public Debt: the Role of Expectations," A merican E conomic Review 78(4), 647-61.

Cavallo, E., 2005. "Output Volatility and Openness to Trade: A Reassessment", manuscript, Kennedy School of G overnment, Harvard University, Cambridge, MA.

Checchi, D and C. Garcia-Peñalosa, 2004. "Risk and the distribution of human capital," E conomics L etters $82(1), 53-61$. 
Cole, H, and T. Kehoe, 1996. "A Self-fulfilling model of Mexico's 1994-95 Debt Crisis," Journal of International E conomics 41(3-4), 309-30.

Corbacho, A., M. García-Escribano and G. Inchauste. 2007. Argentina: Macroeconomic Crisis and Household Vulnerability. Review of D evelopment Economics 11(1), 92-106.

De Janvry, A., and E. Sadoulet, 2000. "Growth, Poverty, and Inequality in Latin America: A Causal Analysis 1970-94," Review of Inome and W ealth 46(3), 267-287.

Diamond, D., and P. Dybvig, 1983. "Bank Runs, D eposit Insurance, and Liquidity," Journal of Political E onomy 91(3), 401-19.

Easterly, W., R. Islam, and J. Stiglitz, 2000. "Shaken and Stirred: Explaining Growth Volatility," in: B. Pleskovic and N. Stern (eds.): Annual Bank Conference on Development Economics. Washington, DC: The World Bank.

Easterly, W., N. Loayza, and P. Montiel, 1997. "Has Latin America's Post-Reform Growth Been D isappointing?," Journal of International E conomics 43(3-4), 287-311.

Edwards, S., and E. Levy-Y eyati, 2005. "Flexible exchange rates as shock absorbers," E uropean E onomic Review 49(8), 2079-2105.

Fernández-Arias, E. and P. Montiel, 2001. "Reform and Growth: All Pain, No Gain?," IMF Staff Papers 48, 522-546.

Gavin, M. and R. Hausmann, 1998. "G rowth with Equity: The Volatility Connection," in Birdsall, N., C. G raham, and R. Sabot, eds, Beyond Trade offs: Market Reform and Equitable $\mathrm{G}$ rowth in L atin A merica, Washington, D C: Inter-A merican D evelopment Bank, pp. 91-109.

González Rozada, M., and E. Levy-Y eyati,. "Global Factors and Emerging Market Spreads," forthcoming, E onomic Journal.

Halac, M. and S.L. Schmukler. 2004. Distributional Effects of Crises: The Financial Channel. Economia.

Hausmann R., and A. Velasco, 2004, "The Causes of Financial Crises: Moral Failure Versus Market Failure," available on line at:

http:// ksghome.harvard.edu/ avelasco/ Files/ Research/Causes of Crises D ec2004.pdf

Kose, M.A., E.S. Prasad, and M.E. Terrones, 2003. "Financial Integration and Macroeconomic Volatility," IM F Staff Papers 50 (Special Issue), 119-42.

Kose, M.A., E.S. Prasad, and M.E. Terrones, 2005. Growth and Volatility in an Era of Globalization. IM F Staff Papers 52 (Special Issue), 31-63.

Kraay, A., 2006. "When Is G rowth Pro-Poor? Evidence from a Panel of Countries." Journal of D evelopment E conomics 80(1), 198-227. 
Laursen, T. and S. Mahajan, 2004. "Volatility, Income Distribution, and Poverty," in: Aizenman, J. and B. Pinto, eds. Managing V olatility and Crisis: A Practitioner's Guide, Washington, DC: The World Bank, pp. 101-136.

Levy Yeyati, E, and F, Sturzeneger, 2007. "Fear of Appreciation," Kennedy School of Government Working Paper 07-047, Harvard University.

Loayza, N., Fajnzylber, P., and C. Calderón, 2005. "Economic Growth in Latin America: Stylized Facts, Explanations and Forecasts," The World Bank Latin American and Caribbean Studies Viewpoints, pp. 156

López, H. forthcoming. "Pro-growth, Pro-poor. Is there a trade-off? in Robert Brent ed., Handbook of Cost Benefit Analysis, Edward Elgar Publishing, forthcoming 2008.

Lopez, H., and L. Servén, 2006. "A normal relationship? Poverty, growth, and inequality," The World Bank, Policy Research Working Paper 3814

McKenzie, D. J., 2004. Aggregate Shocks and Urban Labor Market Responses: Evidence from Argentina?s Financial Crisis. Economic Development and Cultural Change 52, 719-58.

Raddatz, Claudio, 2007. "Are external shocks responsible for the instability of output in lowincome countries?" Journal of D evelopment E conomics 84(1), 155-187

Ramcharan, R., 2007. "D oes the exchange rate regime matter for real shocks? Evidence from windstorms and earthquakes," Journal of International E conomics 73(1), 31-47

Ramey, G. and Ramey, V.. "Cross-Country Evidence on the Link Between Volatility and Growth." A merican E conomic R eview, D ecember 1995, 85(5), pp. 1138-1151.

Thomas, D., K. Beegle, E. Frankenberg, B. Sikokid, J. Strausse and G. Teruel, 2004.

Education in a Crisis. Journal of D evelopment E conomics 74(1), 53-85 
Figure 1

Aggregate Volatility

O utput volatility, 1975-2005

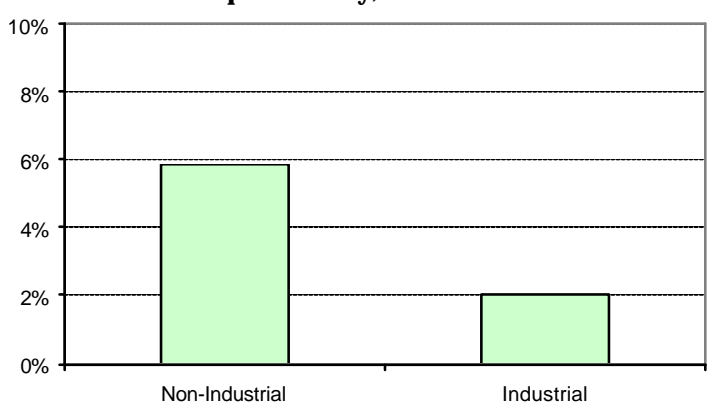

Output drop frequency, 1975-2005

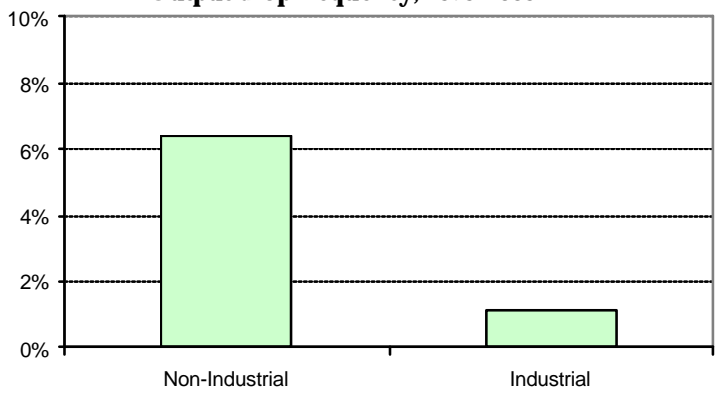

O utput volatility, 1975-2005

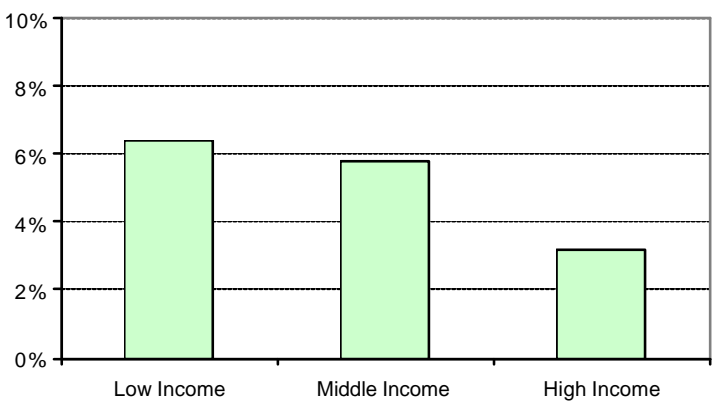

O utput drop frequency, 1975-2005

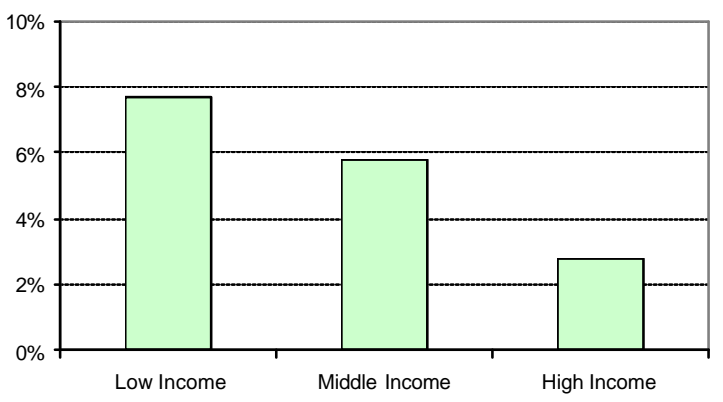

Figure 2

Volatility and Income Distribution

Response of inome inequality to doubling aggregate volatility

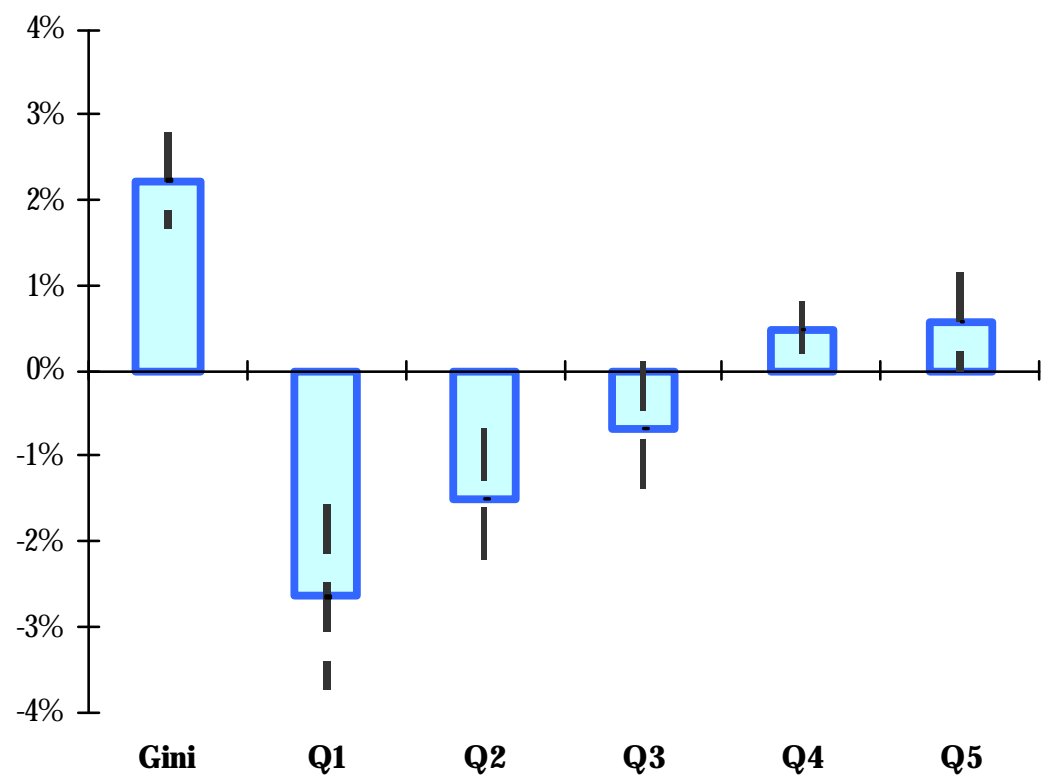


Figure 3

Volatility, Income Distribution and Asymmetric Effects

Percentage change in the $G$ ini coefficient during episodes of output drops and output jumps

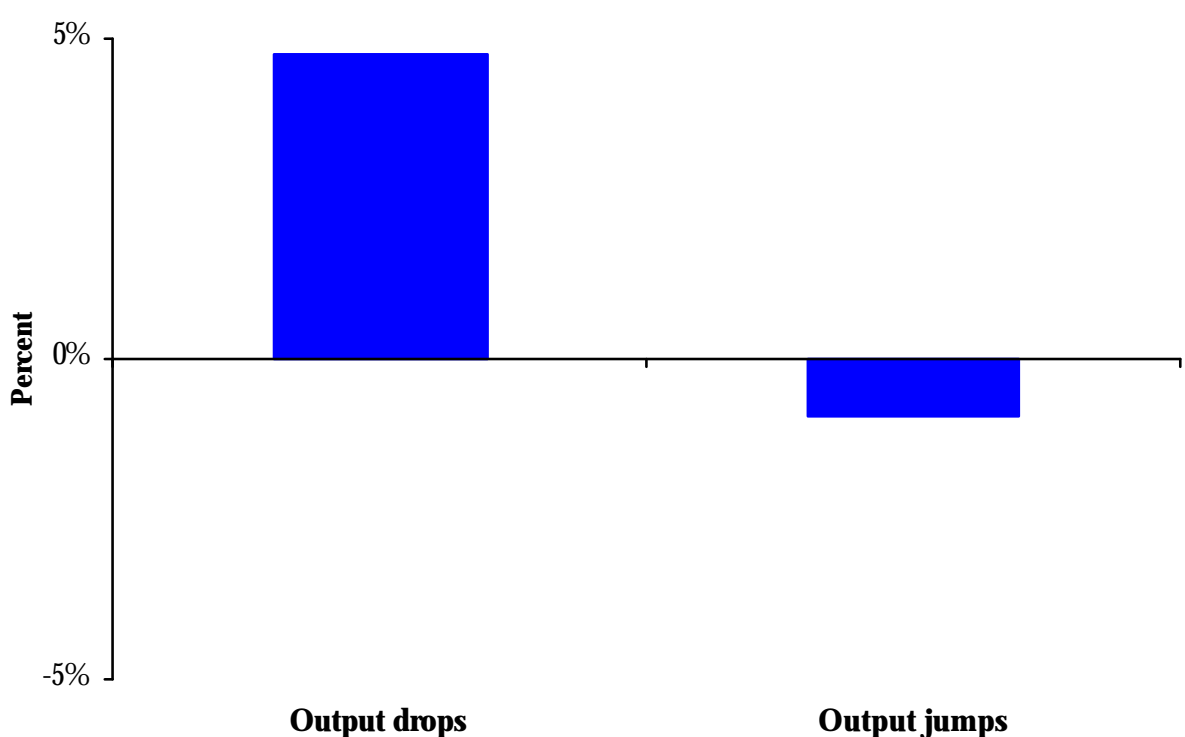

$\mathrm{N}$ ote: $\mathrm{W}$ e use the mean of the $\mathrm{G}$ ini coefficient (in looss) for the full sample and the coefficient estimates of output drops and jumps in oolumn [3] of Table 4 .

Figure 4

Inequality response to aggregate volatility conditional on public spending

G ini coefficient variation conditional on 25th and 75th percentile in distribution of public ex penditure

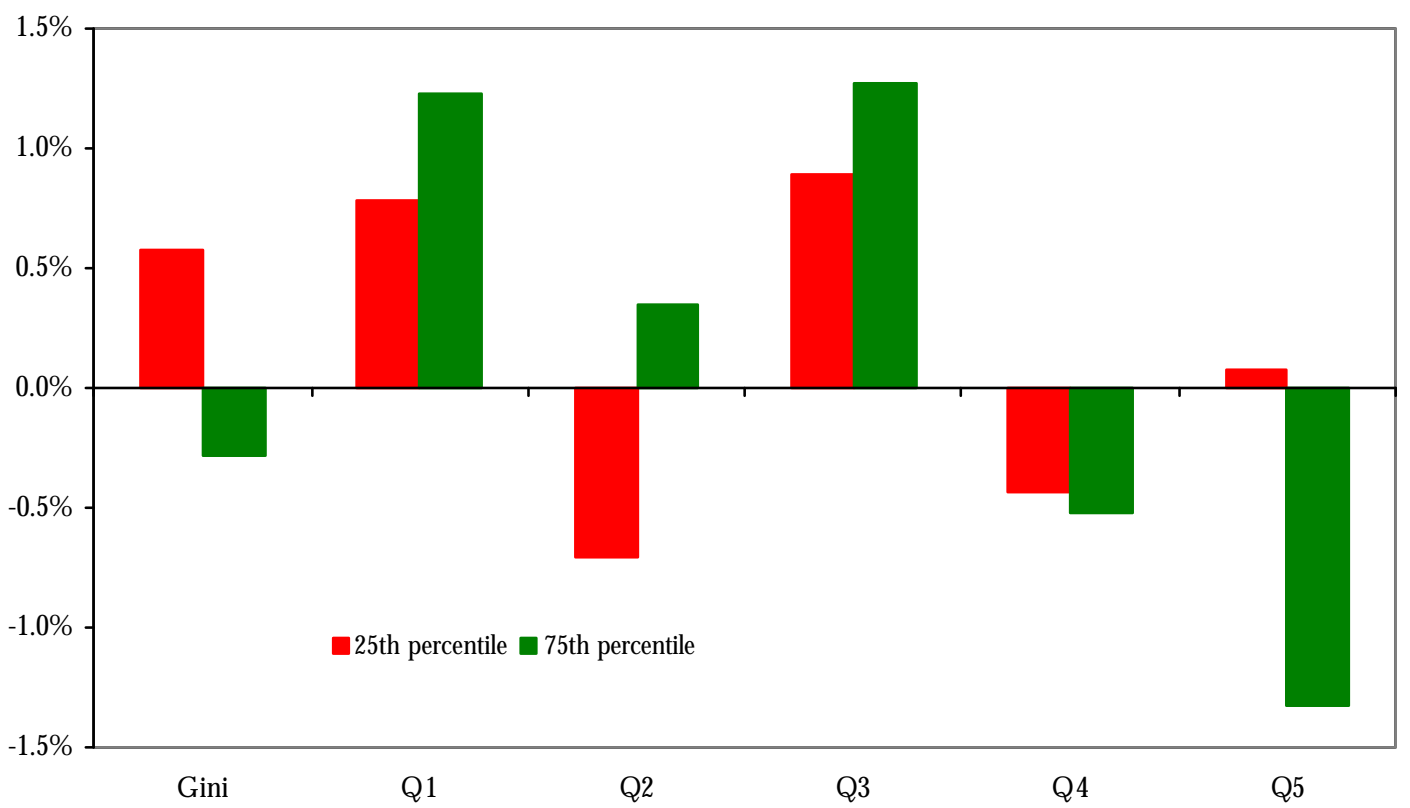

$\mathrm{N}$ ote: W e use the mean coefficient estimates of aggregate volatility and its interaction from $\mathrm{T}$ able 5 . In our calculation we kept the income per capita level constant at its median value. 
Figure 5

Inequality response to " crisis volatility" conditional on public expenditure

$G$ ini coefficient variation onditional on 25 th and 75 th percentile in distribution of public ex penditure

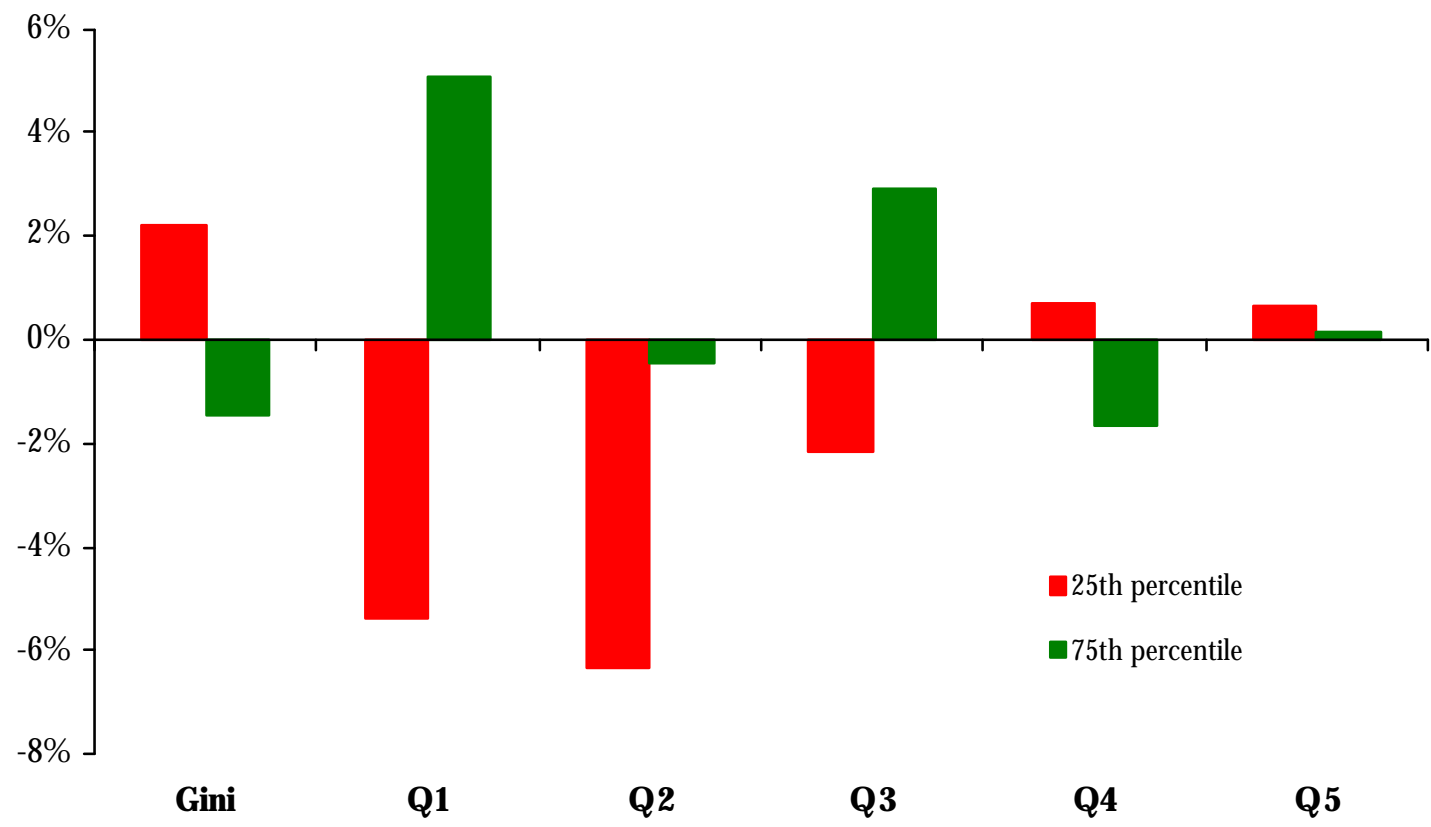

Figure 6

Inequality response to " crisis volatility" conditional on labor regulation

$\mathrm{G}$ ini coefficient variation conditional on 25 th and 75 th percentile in distribution of public ex penditure

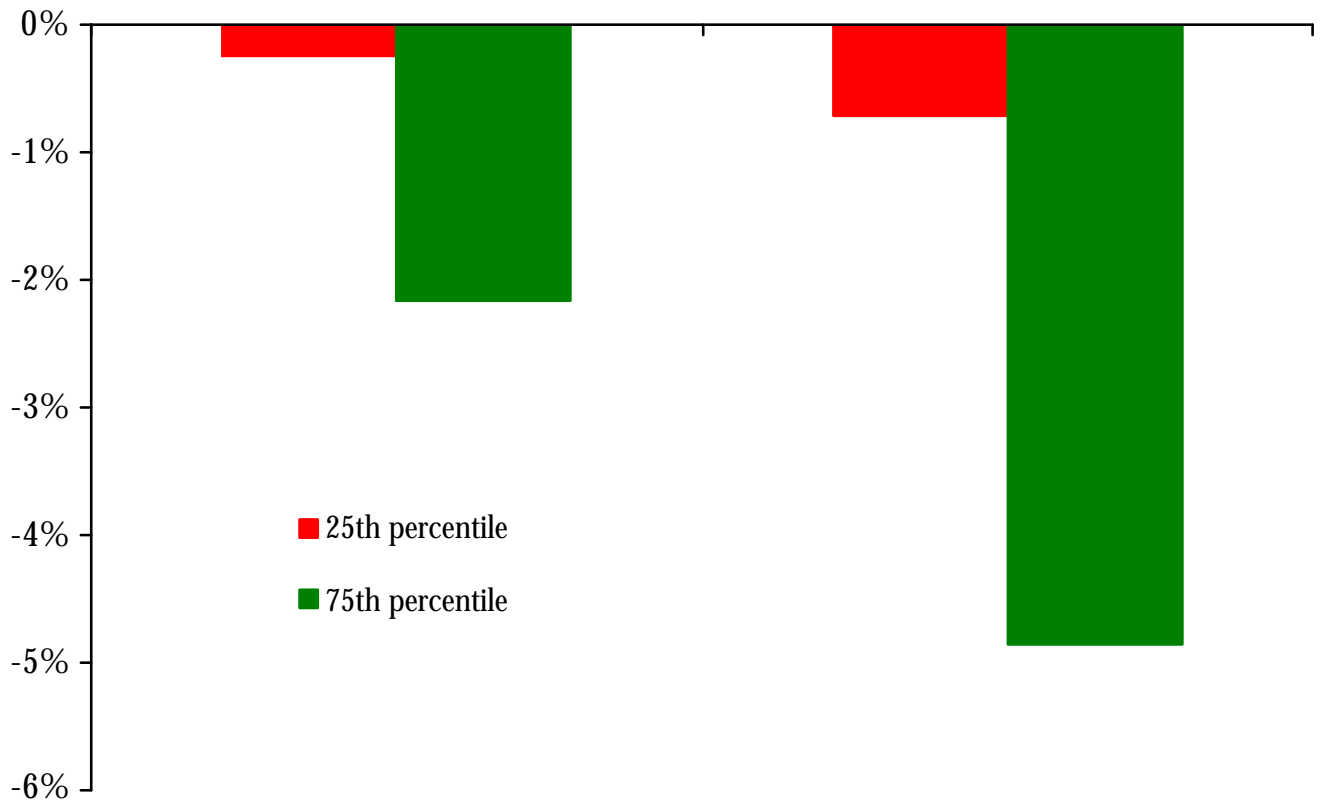

Output drop

Current depth of recession 
Figure 7

Human capital response to volatility conditional on public expenditure

$G$ ini coefficient variation onditional on 25th and 75th perontile in distribution of public ex penditure

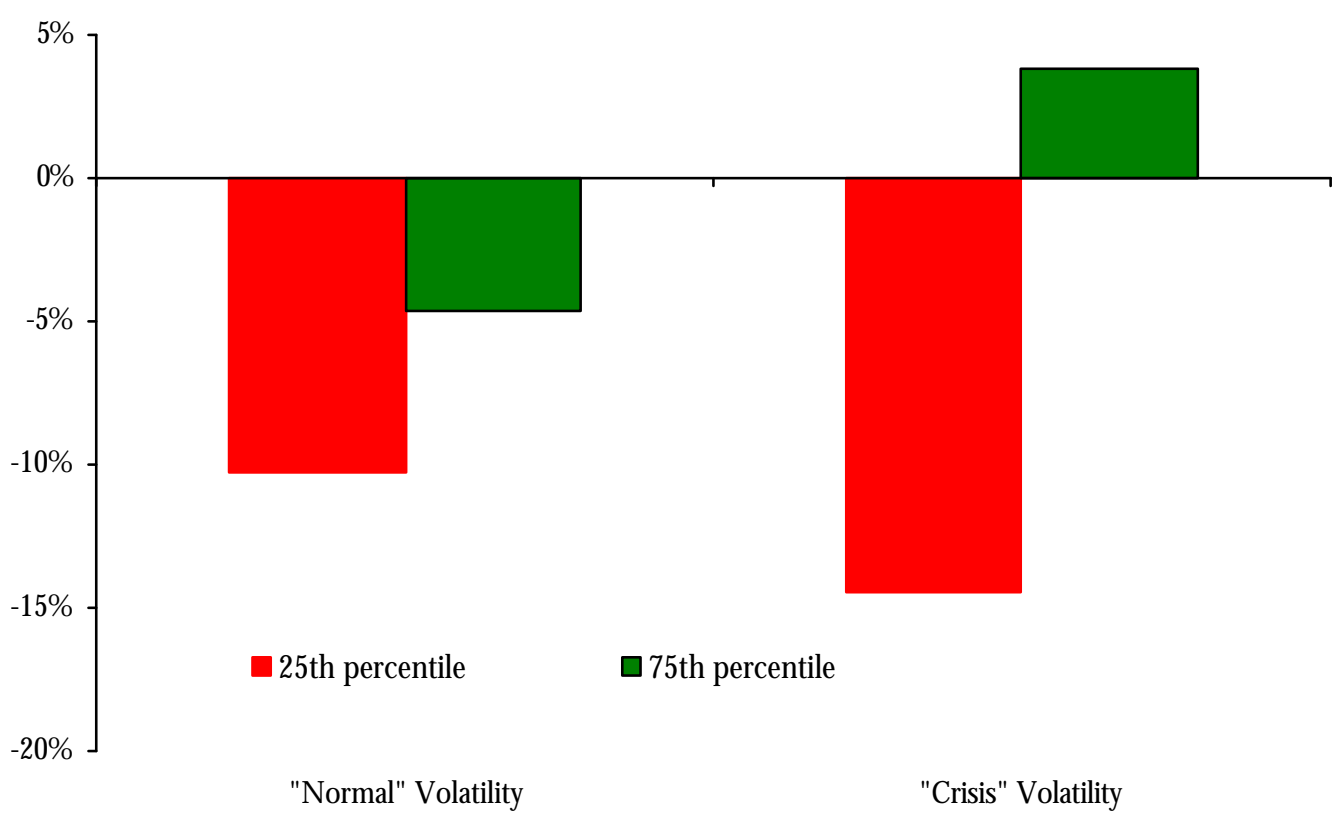

$\mathrm{N}$ ote: U sing coefficient estimates in olumns [2] and [3] of Table 9. 
Table 1

Volatility and income distribution: Baseline regression

Dependent Variable: Gini Coefficient (0-100), end-of-period, in logs

Sample of 75 Countries, 1970-2005 (5-year period observations)

\begin{tabular}{|c|c|c|c|c|c|c|}
\hline \multirow[b]{2}{*}{ Variables } & \multicolumn{4}{|c|}{ All Countries } & \multicolumn{2}{|c|}{ Developing Countries } \\
\hline & $\begin{array}{l}\text { LSDV } \\
{[1]}\end{array}$ & $\begin{array}{l}\text { GMM(D) } \\
{[2]}\end{array}$ & $\begin{array}{l}\text { GMM(S)-Int } \\
{[3]}\end{array}$ & $\begin{array}{c}\text { GMM(S)-Ext } \\
{[4]}\end{array}$ & $\begin{array}{c}\text { GMM(S)-Int } \\
{[5]}\end{array}$ & $\begin{array}{c}\text { GMM(S)-Ext } \\
{[6]}\end{array}$ \\
\hline \multicolumn{7}{|l|}{ Control V ariables } \\
\hline $\begin{array}{l}\text { Real Income Per Capita } \\
\text { (initial level of real G D P per capita, in logs) }\end{array}$ & $\begin{array}{l}0.0504 * \\
(0.031)\end{array}$ & $\begin{array}{l}0.3344 * * \\
(0.119)\end{array}$ & $\begin{array}{l}0.1528 * * \\
(0.035)\end{array}$ & $\begin{array}{l}0.3007 * * \\
(0.073)\end{array}$ & $\begin{array}{l}0.1426 \text { ** } \\
(0.064)\end{array}$ & $\begin{array}{l}0.1638 * * \\
(0.063)\end{array}$ \\
\hline Real Income Per Capita squared & $\begin{array}{l}-0.0036 * \\
(0.002)\end{array}$ & $\begin{array}{l}-0.0246 * * \\
(0.008)\end{array}$ & $\begin{array}{l}-0.0096 * * \\
(0.002)\end{array}$ & $\begin{array}{l}-0.0183 * * \\
(0.005)\end{array}$ & $\begin{array}{l}-0.0099 \text { ** } \\
(0.004)\end{array}$ & $\begin{array}{l}-0.0113 * * \\
(0.004)\end{array}$ \\
\hline $\begin{array}{l}\text { Human Capital } \\
\text { (Secondary enrollment rate, in logs) }\end{array}$ & $\begin{array}{r}-0.0066 \\
(0.013)\end{array}$ & $\begin{array}{l}-0.1098 * * \\
(0.039)\end{array}$ & $\begin{array}{r}-0.0234 \\
(0.017)\end{array}$ & $\begin{array}{l}-0.0698 * * \\
(0.023)\end{array}$ & $\begin{array}{l}-0.0308 \text { ** } \\
(0.012)\end{array}$ & $\begin{array}{l}-0.0199 * * \\
(0.010)\end{array}$ \\
\hline $\begin{array}{l}\text { Countries / Observations } \\
\text { Specification Tests (p-values) }\end{array}$ & $75 / 484$ & $75 / 411$ & $75 / 486$ & $72 / 470$ & $54 / 342$ & $51 / 326$ \\
\hline $\begin{array}{l}\text { - Sargan Test } \\
\text { - 2nd. Order Correlation }\end{array}$ & $\begin{array}{c}. \ddot{8} \\
(0.880)\end{array}$ & $\begin{array}{l}(0.219) \\
(0.444)\end{array}$ & $\begin{array}{l}(0.334) \\
(0.485)\end{array}$ & $\begin{array}{l}(0.403) \\
(0.336)\end{array}$ & $\begin{array}{l}(0.958) \\
(0.878)\end{array}$ & $\begin{array}{l}(0.917) \\
(0.910)\end{array}$ \\
\hline
\end{tabular}

N umbers in parenthesis are robust standard errors. Regressions indude constant and time dummies. * (*) denotes statistical significanœ at the 10 (5) percent level.

0 ur regression indudes the constant and time dummies (not shown above) and the standard errors are computed using the small sample correction by W indmejer (2005).

N ote: L SD V represents the ordinary least squares with dummy variables, G M M (D) represents the G M M -IV differenoe estimator developed by A rellano and Bond (1991), while G M M (S) denotes the G M M-IV system estimator of A rellano and Bover (1995) and Blundell and Bond (1998). Finally, output volatility is instrumented using either "internal instruments" (Int) --that is, own lacs of volatility -- or "ex ternal instruments" (E x t). E x ternal instruments for output volatility are the volatility of terms of trade shocks, volatility of the growth of ex ternal demand, and the volatility

of fluctuations in real foreicm interest rates. 


\section{Table 2}

\section{Volatility and income distribution: Sensitivity to different measures of output volatility}

Sample of 75 Countries, 1970-2005 (5-year period observations)

D ependent V ariable: G ini C oefficient (0-100), end-of-period, in logs / Inoome Shares of Selected Percentiles of the Population (in logs)

E stimation M ethod: G M M-IV System E stimator (A rellano and Bover, 1995; Blundell and Bond, 1998) with ex temal instruments 1

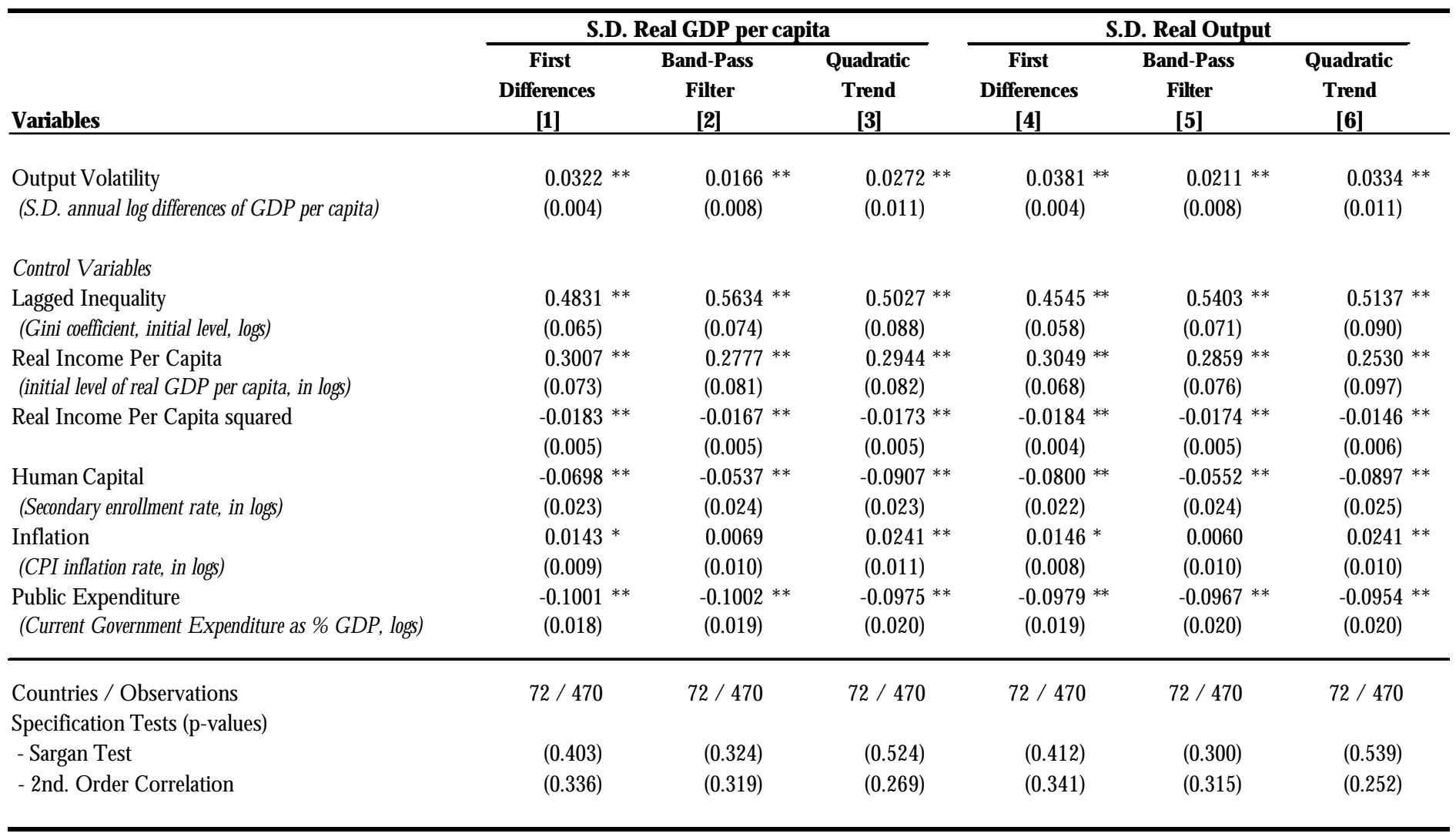

$\mathrm{N}$ umbers in parenthesis are robust standard errors. Regressions indude constant and time dummies. * (**) denotes statistical significanoe at the 10 (5) percent level. 0 ur regression indudes the

the onstant and time dummies (not shown above) and the standard errors are computed using the small sample correction by W indmeijer (2005). Results for the parameter estimate of output volatility in income share regresssions are reported in Tables A .3 and A .4

1/ E x ternal instruments indude the volatility of terms of trade shocks, volatility of the growth of ex ternal demand and volatility of fluctuations in real international interest rates 


\section{Table 3}

\section{Volatility and income distribution: Sensitivity to different measures of income distribution}

Dependent Variable: G ini Coefficient and Income Shares of Income Distribution Q uintiles, end-of-period, in logs

E stimation M ethod: G M M -IV System E stimator (A rellano and Bover, 1995; Blundell and Bond, 1998) with ex ternal instruments $1 /$

Sample of 72 Countries, 1970-2005 (5-year period observations)

\begin{tabular}{|c|c|c|c|c|c|c|}
\hline \multirow[b]{2}{*}{ Variables } & \multirow{2}{*}{$\begin{array}{c}\text { Gini } \\
\text { Coefficient }\end{array}$} & \multicolumn{5}{|c|}{ Income Share of Quintiles of the Income Distribution } \\
\hline & & Q1 & Q2 & Q3 & Q4 & Q5 \\
\hline $\begin{array}{l}\text { Output Volatility } \\
\text { (S.D . annual log differenoes of G D P per capita) }\end{array}$ & $\begin{array}{l}0.0322 * * \\
(0.004)\end{array}$ & $\begin{array}{l}-0.0383 * * \\
(0.008)\end{array}$ & $\begin{array}{l}-0.0219 * * \\
(0.006)\end{array}$ & $\begin{array}{l}-0.0100 * \\
(0.005)\end{array}$ & $\begin{array}{l}0.0068 * * \\
(0.002)\end{array}$ & $\begin{array}{l}0.0083 * * \\
(0.004)\end{array}$ \\
\hline \multicolumn{7}{|l|}{ Control $V$ ariables } \\
\hline Lagged Inequality & $\begin{array}{l}0.4831 \text { ** } \\
(0.065)\end{array}$ & $\begin{array}{l}0.7292 * * \\
(0.026)\end{array}$ & $\begin{array}{l}0.3528 * * \\
(0.030)\end{array}$ & $\begin{array}{l}0.3776 * * \\
(0.024)\end{array}$ & $\begin{array}{l}0.6376 * * \\
(0.025)\end{array}$ & $\begin{array}{l}0.3418 \text { ** } \\
(0.043)\end{array}$ \\
\hline Real Income Per Capita squared & $\begin{array}{l}-0.0183 * * \\
(0.005)\end{array}$ & $\begin{array}{l}0.0361 * * \\
(0.004)\end{array}$ & $\begin{array}{l}0.0542 * * \\
(0.004)\end{array}$ & $\begin{array}{l}0.0379 * * \\
(0.002)\end{array}$ & $\begin{array}{l}-0.0140 * * \\
(0.001)\end{array}$ & $\begin{array}{l}-0.0322 \text { ** } \\
(0.003)\end{array}$ \\
\hline $\begin{array}{l}\text { Human Capital } \\
\text { (Secondary enrollment rate, in logs) }\end{array}$ & $\begin{array}{l}-0.0698 * * \\
(0.023)\end{array}$ & $\begin{array}{l}0.04444^{* *} \\
(0.015)\end{array}$ & $\begin{array}{l}0.1031 * * \\
(0.022)\end{array}$ & $\begin{array}{l}0.0184 \\
(0.015)\end{array}$ & $\begin{array}{l}-0.0137 * * \\
(0.006)\end{array}$ & $\begin{array}{l}-0.0422 \text { ** } \\
(0.014)\end{array}$ \\
\hline $\begin{array}{l}\text { Inflation } \\
\text { (CPI inflation rate, in logs) }\end{array}$ & $\begin{array}{l}0.0143 * \\
(0.009)\end{array}$ & $\begin{array}{l}-0.0294 * \\
(0.018)\end{array}$ & $\begin{array}{l}0.0153 \\
(0.026)\end{array}$ & $\begin{array}{r}-0.0214 \\
(0.014)\end{array}$ & $\begin{array}{l}0.0061 \\
(0.004)\end{array}$ & $\begin{array}{l}0.0530 \text { ** } \\
(0.008)\end{array}$ \\
\hline $\begin{array}{l}\text { Countries / Observations } \\
\text { Specification Tests (p-values) }\end{array}$ & $72 / 470$ & $66 / 433$ & $66 / 433$ & $66 / 433$ & $66 / 433$ & $66 / 433$ \\
\hline $\begin{array}{l}\text { - Sargan Test } \\
\text { - 2nd. Order Correlation }\end{array}$ & $\begin{array}{l}(0.403) \\
(0.336)\end{array}$ & $\begin{array}{l}(0.665) \\
(0.302)\end{array}$ & $\begin{array}{l}(0.508) \\
(0.660)\end{array}$ & $\begin{array}{l}(0.710) \\
(0.695)\end{array}$ & $\begin{array}{l}(0.795) \\
(0.959)\end{array}$ & $\begin{array}{l}(0.918) \\
(0.707)\end{array}$ \\
\hline
\end{tabular}

N umbers in parenthesis are robust standard errors. Regressions indude constant and time dummies. ${ }^{*}(*)$ denotes statistical significanoe at the 10 (5) percent level.

O ur regression indudes the constant and time dummies (not shown above) and the standard errors are computed using the small sample correction by W indmeijer (2005).

1/ Ex ternal instruments indude the volatility of terms of trade shodks, volatility of the growth of ex ternal demand and volatility of flucuations in real international interest rates 


\section{Table 4}

\section{Volatility and income distribution: Asymmetric effects of output fluctuations}

Dependent Variable: G ini Coefficient, end-of-period, in logs

E stimation M ethod: G M M-IV System E stimator (A rellano and Bover, 1995; Blundell and Bond, 1998) with ex ternal instruments 1/

Sample of 72 Countries, 1970-2005 (5-year period observations)

\begin{tabular}{|c|c|c|c|c|c|}
\hline Variables & $\begin{array}{c}\text { Baseline } \\
\text { Specification } \\
\text { [1] } \\
\end{array}$ & $\begin{array}{l}\text { Output } \\
\text { drops } \\
\text { [2] }\end{array}$ & $\begin{array}{l}\text { Output drops } \\
\text { and jumps } \\
\text { [3] } \\
\end{array}$ & $\begin{array}{l}\text { Depth of } \\
\text { recession } \\
\text { [4] }\end{array}$ & $\begin{array}{c}\text { Depth recession } \\
\text { and boom } \\
\text { [5] }\end{array}$ \\
\hline $\begin{array}{l}\text { Output Volatility } \\
\text { (S.D. annual log differences of GDP per capita) }\end{array}$ & $\begin{array}{l}0.0322 \text { ** } \\
(0.004)\end{array}$ & $\begin{array}{c}0.0059 * \\
(0.00)\end{array}$ & $\begin{array}{c}0.0081 * * \\
(0.00)\end{array}$ & $\begin{array}{l}0.0099 \text { ** } \\
(0.00)\end{array}$ & $\begin{array}{l}0.0186 \text { ** } \\
(0.00)\end{array}$ \\
\hline $\begin{array}{l}\text { Adverse Output Events } \\
\text { (O uput drops / D epth of Recession) }\end{array}$ &.. & $\begin{array}{l}0.0540 * * \\
(0.01)\end{array}$ & $\begin{array}{c}0.0464^{* *} \\
(0.01)\end{array}$ & $\begin{array}{c}0.0202 * \\
(0.01)\end{array}$ & $\begin{array}{c}0.0198 * \\
(0.01)\end{array}$ \\
\hline $\begin{array}{l}\text { Positive Output Events } \\
\text { (O uput jumps / D epth of Boom) }\end{array}$ & .. &.. & $\begin{array}{c}-0.0091 * \\
(0.01)\end{array}$ & .. & $\begin{array}{r}-0.0089 \\
(0.01)\end{array}$ \\
\hline \multicolumn{6}{|l|}{ Control $\mathrm{V}$ ariables } \\
\hline Lagged Inequality & $\begin{array}{l}0.4831 \text { ** } \\
(0.065)\end{array}$ & $\begin{array}{l}0.7774 * * \\
(0.018)\end{array}$ & $\begin{array}{l}0.7933 * * \\
(0.025)\end{array}$ & $\begin{array}{l}0.7087 \text { ** } \\
(0.022)\end{array}$ & $\begin{array}{l}0.7328 * * \\
(0.028)\end{array}$ \\
\hline $\begin{array}{l}\text { Real Income Per Capita } \\
\text { (initial level of real GDP per capita, in logs) }\end{array}$ & $\begin{array}{l}0.3007 \text { ** } \\
(0.073)\end{array}$ & $\begin{array}{l}0.2188 * * \\
(0.034)\end{array}$ & $\begin{array}{l}0.2116^{* *} \\
(0.033)\end{array}$ & $\begin{array}{l}0.2911 \text { ** } \\
(0.027)\end{array}$ & $\begin{array}{l}0.2302 \text { ** } \\
(0.037)\end{array}$ \\
\hline Real Income Per Capita squared & $\begin{array}{l}-0.0183 \text { ** } \\
(0.005)\end{array}$ & $\begin{array}{l}-0.0139 * * \\
(0.002)\end{array}$ & $\begin{array}{l}-0.0133 * * \\
(0.002)\end{array}$ & $\begin{array}{l}-0.0196 \text { ** } \\
(0.002)\end{array}$ & $\begin{array}{l}-0.0153 * * \\
(0.002)\end{array}$ \\
\hline $\begin{array}{l}\text { Human Capital } \\
\text { (Secondary enrollment rate, in logs) }\end{array}$ & $\begin{array}{l}-0.0698 * * \\
(0.023)\end{array}$ & $\begin{array}{l}-0.0191 * * \\
(0.007)\end{array}$ & $\begin{array}{l}-0.0162 * * \\
(0.008)\end{array}$ & $\begin{array}{l}-0.0124 * * \\
(0.006)\end{array}$ & $\begin{array}{l}-0.0137 * \\
(0.008)\end{array}$ \\
\hline $\begin{array}{l}\text { Inflation } \\
\text { (C PI inflation rate, in logs) }\end{array}$ & $\begin{array}{l}0.0143 * \\
(0.009)\end{array}$ & $\begin{array}{r}-0.0101 \\
(0.015)\end{array}$ & $\begin{array}{r}-0.0088 \\
(0.013)\end{array}$ & $\begin{array}{r}-0.0061 \\
(0.013)\end{array}$ & $\begin{array}{r}-0.0048 \\
(0.012)\end{array}$ \\
\hline $\begin{array}{l}\text { Public Expenditure } \\
\text { (Current G overnment Expenditure as \% GDP, logs) }\end{array}$ & $\begin{array}{l}-0.1001 \text { ** } \\
(0.018)\end{array}$ & $\begin{array}{l}-0.0346 * * \\
(0.007)\end{array}$ & $\begin{array}{l}-0.0494^{* *} \\
(0.008)\end{array}$ & $\begin{array}{l}-0.0168 * \\
(0.010)\end{array}$ & $\begin{array}{c}-0.0299 * * \\
(0.009)\end{array}$ \\
\hline $\begin{array}{l}\text { Countries / Observations } \\
\text { Specification Tests (p-values) }\end{array}$ & $72 / 470$ & $72 / 470$ & $72 / 470$ & $72 / 470$ & $72 / 470$ \\
\hline $\begin{array}{l}\text { - Sargan Test } \\
\text { - 2nd. O rder Correlation }\end{array}$ & $\begin{array}{l}(0.403) \\
(0.336)\end{array}$ & $\begin{array}{l}(0.725) \\
(0.931)\end{array}$ & $\begin{array}{l}(0.375) \\
(0.943)\end{array}$ & $\begin{array}{l}(0.691) \\
(0.841)\end{array}$ & $\begin{array}{l}(0.597) \\
(0.796)\end{array}$ \\
\hline
\end{tabular}

$\mathrm{N}$ umbers in parenthesis are robust standard errors. Regressions indude constant and time dummies. $*(* *)$ denotes statistical significano at the 10 (5) percent level.

0 ur regression includes the constant and time dummies (not shown above) and the standard errors are computed using the small sample orrection by W indmejer (2005).

1/ E x ternal instruments indude the volatility of terms of trade shocks, volatility of the growth of ex ternal demand and volatility of fluctuations in real international interest rates. 
Table 5

Volatility and income distribution: Mitigating factors

D ependent Variable: G ini Coefficient and Income Shares of Income D istribution Q uintiles, end-of-period, in logs

E stimation M ethod: G M M -IV System E stimator (A rellano and Bover, 1995; Blundell and Bond, 1998) with ex ternal instruments $1 /$

Sample of 72 Countries, 1970-2005 (5-year period observations)

\begin{tabular}{|c|c|c|c|c|c|c|c|c|}
\hline \multirow[b]{2}{*}{ Variables } & \multicolumn{3}{|c|}{ Gini Coefficient } & \multicolumn{5}{|c|}{ Income Share of Q uintiles of the Income Distribution } \\
\hline & [1] & [2] & [3] & Q1 & Q2 & Q3 & Q4 & Q5 \\
\hline $\begin{array}{l}\text { Output Volatility } \\
\text { (S.D. annual log differences of G D P per capita) }\end{array}$ & $\begin{array}{l}0.2454^{* *} \\
(0.024)\end{array}$ & $\begin{array}{l}0.0234 \text { ** } \\
(0.003)\end{array}$ & $\begin{array}{l}0.3171 * * \\
(0.043)\end{array}$ & $\begin{array}{l}-0.1960 * * \\
(0.062)\end{array}$ & $\begin{array}{l}-0.0690 * \\
(0.036)\end{array}$ & $\begin{array}{l}-0.0716 * \\
(0.037)\end{array}$ & $\begin{array}{l}0.0265^{*} \\
(0.014)\end{array}$ & $\begin{array}{l}0.0789 * * \\
(0.025)\end{array}$ \\
\hline O utput Volatility * Real Income per Capita & $\begin{array}{l}-0.0317 * * \\
(0.003)\end{array}$ & .. & $\begin{array}{l}-0.0363 * * \\
(0.006)\end{array}$ & $\begin{array}{l}0.0252 * * \\
(0.008)\end{array}$ & $\begin{array}{l}0.0010 * \\
(0.001)\end{array}$ & $\begin{array}{l}0.0090 * \\
(0.005)\end{array}$ & $\begin{array}{l}-0.0039 * * \\
(0.002)\end{array}$ & $\begin{array}{r}-0.0013 \\
(0.003)\end{array}$ \\
\hline O utput Volatility* Public Expenditure &. & $\begin{array}{l}-0.0127 \text { ** } \\
(0.002)\end{array}$ & $\begin{array}{l}-0.0162 * * \\
(0.003)\end{array}$ & $\begin{array}{l}0.0085^{* *} \\
(0.004)\end{array}$ & $\begin{array}{l}0.0199 * \\
(0.012)\end{array}$ & $\begin{array}{l}0.0071 \text { ** } \\
(0.002)\end{array}$ & $\begin{array}{l}-0.0016 * * \\
(0.001)\end{array}$ & $\begin{array}{l}-0.0263 * * \\
(0.010)\end{array}$ \\
\hline \multicolumn{9}{|l|}{$\underline{\text { Control V ariables }}$} \\
\hline Lagged Inequality & $\begin{array}{l}0.4126 * * \\
(0.040)\end{array}$ & $\begin{array}{l}0.4267 \text { ** } \\
(0.047)\end{array}$ & $\begin{array}{l}0.4854 * * \\
(0.053)\end{array}$ & $\begin{array}{l}0.6918 * * \\
(0.027)\end{array}$ & $\begin{array}{l}0.4199 * * \\
(0.033)\end{array}$ & $\begin{array}{l}0.3608 \text { ** } \\
(0.018)\end{array}$ & $\begin{array}{l}0.5036 * * \\
(0.031)\end{array}$ & $\begin{array}{l}0.4437 * * \\
(0.042)\end{array}$ \\
\hline $\begin{array}{l}\text { Real Income Per Capita } \\
\text { (initial level of real G D P per capita, in logs) }\end{array}$ & $\begin{array}{l}0.3989 * * \\
(0.061)\end{array}$ & $\begin{array}{l}0.3262 \text { ** } \\
(0.068)\end{array}$ & $\begin{array}{l}0.4938 * * \\
(0.065)\end{array}$ & $\begin{array}{l}-0.6564 * * \\
(0.122)\end{array}$ & $\begin{array}{l}-0.7884 \text { ** } \\
(0.080)\end{array}$ & $\begin{array}{l}-0.4900 \text { ** } \\
(0.041)\end{array}$ & $\begin{array}{l}0.2880 * * \\
(0.027)\end{array}$ & $\begin{array}{l}0.4277^{* *} \\
(0.042)\end{array}$ \\
\hline Real Income Per Capita squared & $\begin{array}{l}-0.0244 * * \\
(0.004)\end{array}$ & $\begin{array}{l}-0.0203 * * \\
(0.004)\end{array}$ & $\begin{array}{l}-0.0302 * * \\
(0.004)\end{array}$ & $\begin{array}{l}0.0410 * * \\
(0.008)\end{array}$ & $\begin{array}{l}0.0486 \text { ** } \\
(0.005)\end{array}$ & $\begin{array}{l}0.0329 * * \\
(0.003)\end{array}$ & $\begin{array}{l}-0.0180 * * \\
(0.002)\end{array}$ & $\begin{array}{l}-0.0279 * * \\
(0.003)\end{array}$ \\
\hline $\begin{array}{l}\text { Human Capital } \\
\text { (Secondary enrollment rate, in logs) }\end{array}$ & $\begin{array}{l}-0.0507 * * \\
(0.018)\end{array}$ & $\begin{array}{l}-0.0767 * * \\
(0.013)\end{array}$ & $\begin{array}{l}-0.0376 * * \\
(0.012)\end{array}$ & $\begin{array}{r}0.0161 \\
(0.020)\end{array}$ & $\begin{array}{l}0.1762 \text { ** } \\
(0.018)\end{array}$ & $\begin{array}{l}0.0014 \\
(0.015)\end{array}$ & $\begin{array}{l}-0.0310 * * \\
(0.006)\end{array}$ & $\begin{array}{l}-0.0411 \text { ** } \\
(0.014)\end{array}$ \\
\hline $\begin{array}{l}\text { Inflation } \\
\text { (CPI inflation rate, in logs) }\end{array}$ & $\begin{array}{l}0.0088 \\
(0.007)\end{array}$ & $\begin{array}{l}0.0013 \\
(0.008)\end{array}$ & $\begin{array}{l}0.0244 \\
(0.018)\end{array}$ & $\begin{array}{l}-0.0650 * * \\
(0.024)\end{array}$ & $\begin{array}{l}0.0076 \\
(0.018)\end{array}$ & $\begin{array}{l}-0.0404 * * \\
(0.014)\end{array}$ & $\begin{array}{l}0.0146 * * \\
(0.005)\end{array}$ & $\begin{array}{l}0.0354 \text { ** } \\
(0.014)\end{array}$ \\
\hline $\begin{array}{l}\text { Public Expenditure } \\
\text { (C urrent G overnment E x penditure as \% G D P, logs) }\end{array}$ & $\begin{array}{l}-0.0722 * * \\
(0.014)\end{array}$ & $\begin{array}{l}-0.0778 \text { ** } \\
(0.014)\end{array}$ & $\begin{array}{l}-0.0769 * * \\
(0.017)\end{array}$ & $\begin{array}{l}0.0470 * * \\
(0.014)\end{array}$ & $\begin{array}{l}0.0275 * \\
(0.016)\end{array}$ & $\begin{array}{l}0.0085 \\
(0.009)\end{array}$ & $\begin{array}{l}-0.0227 * * \\
(0.005)\end{array}$ & $\begin{array}{r}-0.0196 \\
(0.015)\end{array}$ \\
\hline Countries / Observations & $72 / 470$ & $72 / 470$ & $72 / 470$ & $66 / 433$ & $66 / 433$ & $66 / 433$ & $66 / 433$ & $66 / 433$ \\
\hline $\begin{array}{l}\text { Specification Tests (p-values) } \\
\text { - Sargan Test } \\
\text { - 2nd. O rder Correlation }\end{array}$ & $\begin{array}{l}(0.686) \\
(0.254)\end{array}$ & $\begin{array}{l}(0.323) \\
(0.329)\end{array}$ & $\begin{array}{l}(0.669) \\
(0.385)\end{array}$ & $\begin{array}{l}(0.798) \\
(0.272)\end{array}$ & $\begin{array}{l}(0.459) \\
(0.552)\end{array}$ & $\begin{array}{l}(0.747) \\
(0.744)\end{array}$ & $\begin{array}{l}(0.747) \\
(0.744)\end{array}$ & $\begin{array}{l}(0.897) \\
(0.779)\end{array}$ \\
\hline
\end{tabular}

$\mathrm{N}$ umbers in parenthesis are robust standard errors. Regressions indude constant and time dummies. * $\left.*^{* *}\right)$ denotes statistical significanœ at the 10 (5) percent level. 0 ur regression indudes the œonstant term and time dummies (not shown above) and the standard errors are computed using the small sample correction by W indmejer (2005).

1/ Ex ternal instruments indude the volatility of terms of trade shodks, volatility of the growth of ex ternal demand and volatility of fluctuations in real international interest rates. 
Table 6

Volatility and income distribution: N onlinear effect of output fluctuations

D ependent Variable: Gini Coefficient and Income Shares of Income Distribution Quintiles, end-of-period, in logs

E stimation M ethod: G M M -IV System E stimator (A rellano and Bover, 1995; Blundell and Bond, 1998) with ex ternal instruments 1/

Sample of 72 Countries, 1970-2005 (5-year period observations)

\begin{tabular}{|c|c|c|c|c|c|c|}
\hline \multirow[b]{2}{*}{ Variables } & \multirow{2}{*}{$\begin{array}{c}\text { Gini } \\
\text { Coefficient }\end{array}$} & \multicolumn{5}{|c|}{ Income Share of Q uintiles of the Income Distribution } \\
\hline & & Q1 & Q2 & Q3 & Q4 & $\mathbf{Q 5}$ \\
\hline $\begin{array}{l}\text { O utput Volatility } \\
\text { (S.D . annual log differenoes of G D P per capita) }\end{array}$ & $\begin{array}{l}0.0110 * * \\
(0.005)\end{array}$ & $\begin{array}{r}-0.0107 \\
(0.011)\end{array}$ & $\begin{array}{c}-0.0142 \\
(0.011)\end{array}$ & $\begin{array}{r}-0.0031 \\
(0.006)\end{array}$ & $\begin{array}{r}-0.0055 \\
(0.112)\end{array}$ & $\begin{array}{l}0.0158 * * \\
(0.007)\end{array}$ \\
\hline Output Volatility* Public Expenditure & $\begin{array}{l}-0.0068 * * \\
(0.002)\end{array}$ & $\begin{array}{l}0.0085 * * \\
(0.003)\end{array}$ & $\begin{array}{l}0.0080 * \\
(0.004)\end{array}$ & $\begin{array}{l}0.0064 * * \\
(0.002)\end{array}$ & $\begin{array}{r}-0.0019 \\
(0.037)\end{array}$ & $\begin{array}{c}-0.0032 * \\
(0.002)\end{array}$ \\
\hline Output D rops & $\begin{array}{l}0.1977 * * \\
(0.060)\end{array}$ & $\begin{array}{l}-0.5763 \text { ** } \\
(0.150)\end{array}$ & $\begin{array}{l}-0.3632 * * \\
(0.103)\end{array}$ & $\begin{array}{l}-0.2764 \text { ** } \\
(0.092)\end{array}$ & $\begin{array}{l}0.1311 \text { ** } \\
(0.033)\end{array}$ & $\begin{array}{l}0.0172 * * \\
(0.007)\end{array}$ \\
\hline Output D rops* Public Expenditure & $\begin{array}{l}-0.0615^{* *} \\
(0.021)\end{array}$ & $\begin{array}{l}0.1879 \text { ** } \\
(0.050)\end{array}$ & $\begin{array}{l}0.1023 * * \\
(0.032)\end{array}$ & $\begin{array}{l}0.0893 \text { ** } \\
(0.031)\end{array}$ & $\begin{array}{l}-0.0427 * * \\
(0.011)\end{array}$ & $\begin{array}{c}-0.0059 * \\
(0.003)\end{array}$ \\
\hline Control V ariables & & & & & & \\
\hline Lagged Inequality & $\begin{array}{l}0.5408 * * \\
(0.065)\end{array}$ & $\begin{array}{l}0.7683 \text { ** } \\
(0.026)\end{array}$ & $\begin{array}{l}0.4462 * * \\
(0.038)\end{array}$ & $\begin{array}{l}0.4047 \text { ** } \\
(0.023)\end{array}$ & $\begin{array}{l}0.7320 * * \\
(0.026)\end{array}$ & $\begin{array}{l}0.4399 * * \\
(0.054)\end{array}$ \\
\hline $\begin{array}{l}\text { Real Income Per Capita } \\
\text { (initial level of real G D P per capita, in logs) }\end{array}$ & $\begin{array}{l}0.1270 * \\
(0.080)\end{array}$ & $\begin{array}{l}-0.6811 \text { ** } \\
(0.101)\end{array}$ & $\begin{array}{l}-0.9013^{* *} \\
(0.072)\end{array}$ & $\begin{array}{l}-0.6443 \text { ** } \\
(0.045)\end{array}$ & $\begin{array}{l}0.2445 \text { ** } \\
(0.018)\end{array}$ & $\begin{array}{l}0.4417 \text { ** } \\
(0.047)\end{array}$ \\
\hline Real Income Per Capita squared & $\begin{array}{l}-0.0089 * \\
(0.005)\end{array}$ & $\begin{array}{l}0.0443 \text { ** } \\
(0.006)\end{array}$ & $\begin{array}{l}0.0573 * * \\
(0.004)\end{array}$ & $\begin{array}{l}0.0416 \text { ** } \\
(0.003)\end{array}$ & $\begin{array}{l}-0.0157 * * \\
(0.001)\end{array}$ & $\begin{array}{l}-0.0280 * * \\
(0.003)\end{array}$ \\
\hline $\begin{array}{l}\text { Human Capital } \\
\text { (Secondary enrollment rate, in logs) }\end{array}$ & $\begin{array}{l}-0.1197 * * \\
(0.025)\end{array}$ & $\begin{array}{l}0.0895 * * \\
(0.036)\end{array}$ & $\begin{array}{l}0.2192 * * \\
(0.042)\end{array}$ & $\begin{array}{l}0.0633 \text { ** } \\
(0.016)\end{array}$ & $\begin{array}{l}-0.0407 \text { ** } \\
(0.005)\end{array}$ & $\begin{array}{l}-0.0799 * * \\
(0.018)\end{array}$ \\
\hline $\begin{array}{l}\text { Inflation } \\
\text { (CPI inflation rate, in logs) }\end{array}$ & $\begin{array}{l}0.0976^{* *} \\
(0.013)\end{array}$ & $\begin{array}{l}0.0152 \\
(0.026)\end{array}$ & $\begin{array}{l}0.0767 * * \\
(0.030)\end{array}$ & $\begin{array}{r}-0.0117 \\
(0.018)\end{array}$ & $\begin{array}{r}0.0026 \\
(0.006)\end{array}$ & $\begin{array}{l}0.0508 \text { ** } \\
(0.018)\end{array}$ \\
\hline $\begin{array}{l}\text { Public Expenditure } \\
\text { (C urrent G overnment } \mathrm{E} \text { x penditure as \% G D P, logs) }\end{array}$ & $\begin{array}{l}-0.0480 * * \\
(0.024)\end{array}$ & $\begin{array}{l}-0.1229 * * \\
(0.033)\end{array}$ & $\begin{array}{l}-0.0675^{*} \\
(0.042)\end{array}$ & $\begin{array}{l}0.0223 \\
(0.019)\end{array}$ & $\begin{array}{l}0.0127 * \\
(0.008)\end{array}$ & $\begin{array}{l}-0.0362 * * \\
(0.017)\end{array}$ \\
\hline $\begin{array}{l}\text { Countries / Observations } \\
\text { Specification Tests ( } p \text {-values) }\end{array}$ & $72 / 470$ & $66 / 433$ & $66 / 433$ & $66 / 433$ & $66 / 433$ & $66 / 433$ \\
\hline $\begin{array}{l}\text { - Sargan Test } \\
\text { - 2nd. Order Correlation }\end{array}$ & $\begin{array}{l}(0.551) \\
(0.993)\end{array}$ & $\begin{array}{l}(0.542) \\
(0.376)\end{array}$ & $\begin{array}{l}(0.759) \\
(0.690)\end{array}$ & $\begin{array}{l}(0.811) \\
(0.655)\end{array}$ & $\begin{array}{l}(0.826) \\
(0.975)\end{array}$ & $\begin{array}{l}(0.900) \\
(0.963)\end{array}$ \\
\hline
\end{tabular}

N umbers in parenthesis are robust standard errors. Regressions indude constant and time dummies. * (**) denotes statistical significanœ at the 10 (5) percent level.

0 ur regression indudes the constant and time dummies (not shown above) and the standard errors are computed using the small sample correction by W indmeijer (2005).

1/ E x ternal instruments indude the volatility of terms of trade shocks, volatility of the growth of ex ternal demand and volatility of fluctuations in real international interest rates. 
Table 7

Volatility and income distribution: The role of labor market protection

Dependent Variable: Gini Coefficient and Income Shares of Income Distribution Q uintiles, end-of-period, in logs E stimation M ethod: G M M-IV System E stimator (A rellano and Bover, 1995; Blundell and Bond, 1998) with ex ternal instruments $1 /$ Sample of 72 C ountries, 1970-2005 (5-year period observations)

\begin{tabular}{|c|c|c|c|c|c|c|}
\hline \multirow[b]{2}{*}{ Variables } & \multicolumn{3}{|c|}{ Output Drops } & \multicolumn{3}{|c|}{ Current Depth of Recession } \\
\hline & $\begin{array}{c}\text { [1] } \\
\text { Minimum } \\
\text { Wages }\end{array}$ & $\begin{array}{c}\text { [2] } \\
\text { Difficulty of } \\
\text { Fining } \\
\end{array}$ & $\begin{array}{c}\text { [3] } \\
\text { Fining } \\
\text { Costs } \\
\end{array}$ & $\begin{array}{c}{[4]} \\
\text { Minimum } \\
\text { Wages } \\
\end{array}$ & $\begin{array}{c}\text { [5] } \\
\text { Difficulty of } \\
\text { Fining } \\
\end{array}$ & $\begin{array}{c}\text { [6] } \\
\text { Fining } \\
\text { Costs } \\
\end{array}$ \\
\hline $\begin{array}{l}\text { Output Volatility } \\
\text { (S.D . annual log differenoes of G D P per capita) }\end{array}$ & $\begin{array}{l}0.0087 \\
(0.007)\end{array}$ & $\begin{array}{l}0.0357 \text { ** } \\
(0.009)\end{array}$ & $\begin{array}{l}0.0038 \\
(0.013)\end{array}$ & $\begin{array}{r}-0.0036 \\
(0.009)\end{array}$ & $\begin{array}{l}0.0510 \text { ** } \\
(0.016)\end{array}$ & $\begin{array}{r}-0.0085 \\
(0.012)\end{array}$ \\
\hline Output Volatility* Public Expenditure & $\begin{array}{r}-0.0022 \\
(0.003)\end{array}$ & $\begin{array}{r}-0.0037 \\
(0.003)\end{array}$ & $\begin{array}{l}-0.0089 * * \\
(0.002)\end{array}$ & $\begin{array}{l}-0.0138 * * \\
(0.004)\end{array}$ & $\begin{array}{l}-0.0072 \text { ** } \\
(0.003)\end{array}$ & $\begin{array}{l}-0.0071 \text { ** } \\
(0.003)\end{array}$ \\
\hline O utput Volatility * Labor Market Rigidities & $\begin{array}{r}-0.0030 \\
(0.004)\end{array}$ & $\begin{array}{l}-0.0005 * * \\
(0.000)\end{array}$ & $\begin{array}{l}0.0000 \\
(0.000)\end{array}$ & $\begin{array}{r}-0.0037 \\
(0.005)\end{array}$ & $\begin{array}{l}-0.0007 \text { ** } \\
(0.000)\end{array}$ & $\begin{array}{l}0.0003 \\
(0.001)\end{array}$ \\
\hline $\begin{array}{l}\text { O utput D rops } \\
\text { (S.D . annual log differenoes of G D P per capita) }\end{array}$ & $\begin{array}{l}0.1729 * * \\
(0.060)\end{array}$ & $\begin{array}{l}0.2133 * * \\
(0.094)\end{array}$ & $\begin{array}{l}0.1575 \text { ** } \\
(0.080)\end{array}$ &.. & .. & .. \\
\hline Output D rops* Public Expenditure & $\begin{array}{l}-0.0557 * * \\
(0.020)\end{array}$ & $\begin{array}{l}-0.0698 * * \\
(0.032)\end{array}$ & $\begin{array}{l}-0.0457 * \\
(0.026)\end{array}$ & .. & .. & .. \\
\hline O utput D rops * Labor Market Rigidities & $\begin{array}{l}0.0036 * \\
(0.002)\end{array}$ & $\begin{array}{l}-0.0007^{*} \\
(0.000)\end{array}$ & $\begin{array}{r}-0.0003 \\
(0.000)\end{array}$ & .. & .. & .. \\
\hline Current Depth of Recession (CDR) & .. & .. &.. & $\begin{array}{l}0.2085 * * \\
(0.085)\end{array}$ & $\begin{array}{l}0.3036 \text { ** } \\
(0.080)\end{array}$ & $\begin{array}{l}0.3340 \text { ** } \\
(0.070)\end{array}$ \\
\hline CDR * Public Expenditure & .. & .. & .. & $\begin{array}{l}-0.0584 * * \\
(0.027)\end{array}$ & $\begin{array}{l}-0.0993 \text { ** } \\
(0.027)\end{array}$ & $\begin{array}{l}-0.1107 \text { ** } \\
(0.023)\end{array}$ \\
\hline CD R * Labor Market Rigidities & .. & .. & .. & $\begin{array}{l}0.0067 \text { ** } \\
(0.002)\end{array}$ & $\begin{array}{l}-0.0015 \text { ** } \\
(0.000)\end{array}$ & $\begin{array}{l}-0.0008 \text { ** } \\
(0.000)\end{array}$ \\
\hline \multicolumn{7}{|l|}{ Control V ariables } \\
\hline Lagged Inequality & $\begin{array}{l}0.8785 \text { ** } \\
(0.040)\end{array}$ & $\begin{array}{l}0.2649 \text { ** } \\
(0.035)\end{array}$ & $\begin{array}{l}0.3103 \text { ** } \\
(0.044)\end{array}$ & $\begin{array}{l}0.6543 * * \\
(0.083)\end{array}$ & $\begin{array}{l}0.4795 \text { ** } \\
(0.048)\end{array}$ & $\begin{array}{l}0.4428 \text { ** } \\
(0.043)\end{array}$ \\
\hline $\begin{array}{l}\text { Real Income Per Capita } \\
\text { (initial level of real G D P per capita, in logs) }\end{array}$ & $\begin{array}{l}0.2113 * * \\
(0.074)\end{array}$ & $\begin{array}{l}0.7363 * * \\
(0.057)\end{array}$ & $\begin{array}{l}0.6927 * * \\
(0.064)\end{array}$ & $\begin{array}{l}0.2574 * * \\
(0.117)\end{array}$ & $\begin{array}{l}0.4782 * * \\
(0.067)\end{array}$ & $\begin{array}{l}0.5170 \text { ** } \\
(0.065)\end{array}$ \\
\hline Real Income Per Capita squared & $\begin{array}{l}-0.0141 \text { ** } \\
(0.005)\end{array}$ & $\begin{array}{l}-0.0463 \text { ** } \\
(0.004)\end{array}$ & $\begin{array}{l}-0.0428 * * \\
(0.004)\end{array}$ & $\begin{array}{l}-0.0156 \text { ** } \\
(0.007)\end{array}$ & $\begin{array}{l}-0.0305 \text { ** } \\
(0.004)\end{array}$ & $\begin{array}{l}-0.0318 \text { ** } \\
(0.004)\end{array}$ \\
\hline $\begin{array}{l}\text { Human Capital } \\
\text { (Secondary enrollment rate, in logs) }\end{array}$ & $\begin{array}{l}-0.0436 * * \\
(0.015)\end{array}$ & $\begin{array}{l}-0.1201 * * \\
(0.024)\end{array}$ & $\begin{array}{l}-0.1330 * * \\
(0.012)\end{array}$ & $\begin{array}{l}-0.0830 * * \\
(0.036)\end{array}$ & $\begin{array}{l}-0.1346 * * \\
(0.024)\end{array}$ & $\begin{array}{l}-0.1447 \text { ** } \\
(0.017)\end{array}$ \\
\hline $\begin{array}{l}\text { Inflation } \\
\text { (CPI inflation rate, in logs) }\end{array}$ & $\begin{array}{r}-0.0112 \\
(0.018)\end{array}$ & $\begin{array}{r}-0.0116 \\
(0.012)\end{array}$ & $\begin{array}{l}0.0060 \\
(0.019)\end{array}$ & $\begin{array}{r}-0.0162 \\
(0.027)\end{array}$ & $\begin{array}{c}-0.0088 \\
(0.016)\end{array}$ & $\begin{array}{l}0.0000 \\
(0.019)\end{array}$ \\
\hline $\begin{array}{l}\text { Public Expenditure } \\
\text { (C urrent G overnment E x penditure as \% G D P, logs) }\end{array}$ & $\begin{array}{l}0.0463 * \\
(0.024)\end{array}$ & $\begin{array}{l}-0.0795 \text { ** } \\
(0.022)\end{array}$ & $\begin{array}{l}-0.1085 * * \\
(0.018)\end{array}$ & $\begin{array}{l}-0.0563 * \\
(0.032)\end{array}$ & $\begin{array}{l}-0.0276 \\
(0.024)\end{array}$ & $\begin{array}{l}-0.0822 * * \\
(0.018)\end{array}$ \\
\hline $\begin{array}{l}\text { Countries / O bservations } \\
\text { Specification Tests (p-values) }\end{array}$ & $59 / 392$ & $72 / 470$ & $72 / 470$ & $59 / 392$ & $72 / 470$ & $72 / 470$ \\
\hline $\begin{array}{l}\text { - Sargan Test } \\
\text { - 2nd. O rder Correlation }\end{array}$ & $\begin{array}{l}(0.950) \\
(0.892)\end{array}$ & $\begin{array}{l}(0.468) \\
(0.282)\end{array}$ & $\begin{array}{l}(0.433) \\
(0.268)\end{array}$ & $\begin{array}{l}(0.933) \\
(0.272)\end{array}$ & $\begin{array}{l}(0.770) \\
(0.314)\end{array}$ & $\begin{array}{l}(0.603) \\
(0.240)\end{array}$ \\
\hline
\end{tabular}

$\mathrm{N}$ umbers in parenthesis are robust standard errors. Regressions indude constant and time dummies. * $\left.{ }^{* *}\right)$ denotes statistical significanœ at the 10 (5) percent level.

0 ur regression indudes the constant and time dummies (not shown above) and the standard errors are computed using the small sample correction by W indmeijer (2005).

1/ Ex ternal instruments indude the volatility of terms of trade shocks, volatility of the growth of ex ternal demand and volatility of fluctuations in real international interest rates. 
Table 8

Volatility and factor distribution: Who camies the burden?

Dependent Variable: Ratio of Retribution to Capital to Labor Compensation, (rK / wL)

E stimation M ethod: G M M-IV System E stimator (A rellano and Bover, 1995; Blundell and Bond, 1998) with ex ternal instruments 1

Sample of 48 Countries, 1970-2005 (5-year period observations)

\begin{tabular}{|c|c|c|c|c|c|c|c|c|c|}
\hline \multirow[b]{2}{*}{ Variables } & \multirow[b]{2}{*}{$\begin{array}{c}\text { Baseline } \\
{[1]}\end{array}$} & \multirow{2}{*}{$\begin{array}{c}\text { Firing } \\
\text { Cost } \\
{[2]} \\
\end{array}$} & \multirow{2}{*}{$\begin{array}{c}\text { Difficulting } \\
\text { of Firing } \\
{[3]}\end{array}$} & \multicolumn{3}{|c|}{ Output drops } & \multicolumn{3}{|c|}{ Current depth of recession (CDR) } \\
\hline & & & & [4] & $\begin{array}{c}\text { Firing Cost } \\
{[5]}\end{array}$ & $\begin{array}{c}\text { Diff. Firing } \\
\text { [6] }\end{array}$ & [7] & $\begin{array}{c}\text { Fining Cost } \\
{[8]}\end{array}$ & $\begin{array}{c}\text { Diff. Firing } \\
{[9]}\end{array}$ \\
\hline $\begin{array}{l}\text { Output Volatility (Vdy) } \\
\text { (S.D . annual log differenoes of G D P per capita) }\end{array}$ & $\begin{array}{l}0.7543 \text { ** } \\
(0.131)\end{array}$ & $\begin{array}{l}1.0362 \text { ** } \\
(0.115)\end{array}$ & $\begin{array}{l}0.4655 \text { ** } \\
(0.173)\end{array}$ & $\begin{array}{l}0.6900 \text { ** } \\
(0.146)\end{array}$ & $\begin{array}{l}0.7312 \text { ** } \\
(0.190)\end{array}$ & $\begin{array}{l}1.1543 * * \\
(0.223)\end{array}$ & $\begin{array}{l}0.8813 \text { ** } \\
(0.156)\end{array}$ & $\begin{array}{l}0.6720 \text { ** } \\
(0.270)\end{array}$ & $\begin{array}{r}-0.0094 \\
(0.264)\end{array}$ \\
\hline Vdy* Public Expenditure & $\begin{array}{l}-0.2496 * * \\
(0.045)\end{array}$ & $\begin{array}{l}-0.3335 * * \\
(0.038)\end{array}$ & $\begin{array}{l}-0.1813 * * \\
(0.062)\end{array}$ & $\begin{array}{l}-0.2381 * * \\
(0.049)\end{array}$ & $\begin{array}{l}-0.2269 * * \\
(0.063)\end{array}$ & $\begin{array}{l}-0.4398 * * \\
(0.073)\end{array}$ & $\begin{array}{l}-0.2782 * * \\
(0.046)\end{array}$ & $\begin{array}{l}-0.2028 \text { ** } \\
(0.081)\end{array}$ & $\begin{array}{l}-0.0342 \\
(0.078)\end{array}$ \\
\hline Vdy * Labor market rigidities & .. & $\begin{array}{l}-0.0009 * * \\
(0.000)\end{array}$ & $\begin{array}{l}0.0013 \\
(0.002)\end{array}$ & .. & $\begin{array}{l}-0.0009 * * \\
(0.000)\end{array}$ & $\begin{array}{l}0.0023 \\
(0.002)\end{array}$ & .. & $\begin{array}{l}-0.0009 * * \\
(0.000)\end{array}$ & $\begin{array}{l}0.0027 * \\
(0.002)\end{array}$ \\
\hline Extreme Output Event (EOE) & .. &.. & .. & $\begin{array}{l}1.4035 \text { ** } \\
(0.490)\end{array}$ & $\begin{array}{l}0.2063 \\
(0.582)\end{array}$ & $\begin{array}{l}1.9585 * * \\
(0.390)\end{array}$ & $\begin{array}{l}0.5318 * \\
(0.288)\end{array}$ & $\begin{array}{l}0.5501 * \\
(0.337)\end{array}$ & $\begin{array}{l}1.0501 \text { ** } \\
(0.205)\end{array}$ \\
\hline EOE * Public Expenditure & .. & .. & .. & $\begin{array}{l}-0.4711 \text { ** } \\
(0.176)\end{array}$ & $\begin{array}{r}-0.0557 \\
(0.178)\end{array}$ & $\begin{array}{l}-0.5861 * * \\
(0.142)\end{array}$ & $\begin{array}{l}-0.2354 * * \\
(0.102)\end{array}$ & $\begin{array}{l}-0.1858 * \\
(0.107)\end{array}$ & $\begin{array}{l}-0.2831 \text { ** } \\
(0.081)\end{array}$ \\
\hline EOE * Labor market rigidities & .. & .. & .. &.. & $\begin{array}{l}0.0000 \\
(0.001)\end{array}$ & $\begin{array}{l}-0.0020 * * \\
(0.001)\end{array}$ & .. & $\begin{array}{l}0.0003 \\
(0.001)\end{array}$ & $\begin{array}{l}-0.0079 * * \\
(0.002)\end{array}$ \\
\hline \multicolumn{10}{|l|}{ Control V ariables } \\
\hline Lagged (rk/ wL) & $\begin{array}{l}0.6150 \text { ** } \\
(0.028)\end{array}$ & $\begin{array}{l}0.5181 \text { ** } \\
(0.033)\end{array}$ & $\begin{array}{l}0.6134 \text { ** } \\
(0.036)\end{array}$ & $\begin{array}{l}0.6095 * * \\
(0.046)\end{array}$ & $\begin{array}{l}0.5925 \text { ** } \\
(0.038)\end{array}$ & $\begin{array}{l}0.4303 * * \\
(0.050)\end{array}$ & $\begin{array}{l}0.5754 \text { ** } \\
(0.045)\end{array}$ & $\begin{array}{l}0.6273 \text { ** } \\
(0.051)\end{array}$ & $\begin{array}{l}0.6982 \text { ** } \\
(0.042)\end{array}$ \\
\hline $\begin{array}{l}\text { Real Income Per Capita } \\
\text { (initial level of real G D P per capita, in logs) }\end{array}$ & $\begin{array}{l}0.3249 \text { ** } \\
(0.095)\end{array}$ & $\begin{array}{l}1.0004 * * \\
(0.157)\end{array}$ & $\begin{array}{l}0.5252 * * \\
(0.192)\end{array}$ & $\begin{array}{l}0.2345 \text { ** } \\
(0.110)\end{array}$ & $\begin{array}{l}0.4180 * * \\
(0.129)\end{array}$ & $\begin{array}{l}0.3250 * \\
(0.194)\end{array}$ & $\begin{array}{l}0.5681 \text { ** } \\
(0.159)\end{array}$ & $\begin{array}{l}0.5047 * * \\
(0.185)\end{array}$ & $\begin{array}{l}0.3789 * \\
(0.200)\end{array}$ \\
\hline Real Income Per Capita squared & $\begin{array}{l}-0.0169 * * \\
(0.006)\end{array}$ & $\begin{array}{l}-0.0593 * * \\
(0.010)\end{array}$ & $\begin{array}{l}-0.0301 * * \\
(0.012)\end{array}$ & $\begin{array}{l}-0.0151 * * \\
(0.007)\end{array}$ & $\begin{array}{l}-0.0238 * * \\
(0.008)\end{array}$ & $\begin{array}{l}-0.0203 * \\
(0.012)\end{array}$ & $\begin{array}{l}-0.0330 * * \\
(0.009)\end{array}$ & $\begin{array}{l}-0.0271 * * \\
(0.011)\end{array}$ & $\begin{array}{l}-0.0207 * \\
(0.012)\end{array}$ \\
\hline $\begin{array}{l}\text { Human Capital } \\
\text { (Secondary enrollment rate, in logs) }\end{array}$ & $\begin{array}{l}-0.1751 * * \\
(0.040)\end{array}$ & $\begin{array}{l}-0.2431 * * \\
(0.037)\end{array}$ & $\begin{array}{l}-0.1771 * * \\
(0.045)\end{array}$ & $\begin{array}{l}-0.1075 \text { ** } \\
(0.044)\end{array}$ & $\begin{array}{l}-0.2491 * * \\
(0.050)\end{array}$ & $\begin{array}{l}-0.0638 * \\
(0.036)\end{array}$ & $\begin{array}{l}-0.2377 * * \\
(0.050)\end{array}$ & $\begin{array}{l}-0.3285 * * \\
(0.074)\end{array}$ & $\begin{array}{l}-0.1956 * * \\
(0.054)\end{array}$ \\
\hline $\begin{array}{l}\text { Inflation } \\
\text { (CPI inflation rate, in logs) }\end{array}$ & $\begin{array}{l}-0.2469 * * \\
(0.042)\end{array}$ & $\begin{array}{l}-0.2649 * * \\
(0.036)\end{array}$ & $\begin{array}{l}-0.1996 * * \\
(0.058)\end{array}$ & $\begin{array}{l}-0.2339 \text { ** } \\
(0.064)\end{array}$ & $\begin{array}{l}-0.2261 \text { ** } \\
(0.064)\end{array}$ & $\begin{array}{l}-0.4572 * * \\
(0.062)\end{array}$ & $\begin{array}{l}-0.1725 \text { ** } \\
(0.047)\end{array}$ & $\begin{array}{l}-0.2172 \text { ** } \\
(0.060)\end{array}$ & $\begin{array}{l}-0.2384 \text { ** } \\
(0.069)\end{array}$ \\
\hline $\begin{array}{l}\text { Public Expenditure } \\
\text { (C urrent G overnment } \mathrm{E} \text { x penditure as \% G D P, looss) }\end{array}$ & $\begin{array}{l}-0.3779 * * \\
(0.048)\end{array}$ & $\begin{array}{l}-0.3025 * * \\
(0.052)\end{array}$ & $\begin{array}{l}-0.3249 * * \\
(0.056)\end{array}$ & $\begin{array}{l}-0.1811 \text { ** } \\
(0.071)\end{array}$ & $\begin{array}{l}-0.2415 * * \\
(0.072)\end{array}$ & $\begin{array}{l}-0.2316 * * \\
(0.038)\end{array}$ & $\begin{array}{l}-0.2175 * * \\
(0.051)\end{array}$ & $\begin{array}{l}-0.2642 \text { ** } \\
(0.061)\end{array}$ & $\begin{array}{l}-0.3071 \text { ** } \\
(0.056)\end{array}$ \\
\hline $\begin{array}{l}\text { Countries / Observations } \\
\text { Specification Tests (p-values) }\end{array}$ & $48 / 251$ & $48 / 251$ & $48 / 251$ & $48 / 251$ & $48 / 251$ & $48 / 251$ & $48 / 251$ & $48 / 251$ & $48 / 251$ \\
\hline - Sargan Test & $(0.707)$ & $(0.621)$ & $(0.886)$ & $(0.599)$ & $(0.401)$ & $(0.324)$ & $(0.328)$ & $(0.432)$ & $(0.411)$ \\
\hline - 2nd. Order Correlation & $(0.460)$ & $(0.466)$ & $(0.342)$ & $(0.492)$ & $(0.548)$ & $(0.252)$ & $(0.681)$ & $(0.503)$ & $(0.326)$ \\
\hline
\end{tabular}

$\mathrm{N}$ umbers in parenthesis are robust standard errors. Regressions indude onstant and time dummies. * (**) denotes statistical significanoe at the 10 (5) peroent leve. Standard errors are oomputed using the small sample corredion by W indmejer (2005).

1/ Ex ternal instruments indude the volatility of terms of trade shocks, volatility of the growth of ex ternal demand and volatility of fluctuations in real international interest rates. 


\section{Table 9 \\ Volatility and education}

D ependent Variable: Enrollment Rate in Secondary Schooling (in logs)

E stimation M ethod: G M M -IV System E stimator (A rellano and Bover, 1995; Blundell and Bond, 1998) with ex ternal instruments $1 /$

Sample of 48 C ountries, 1970-2005 (5-year period observations)

\begin{tabular}{|c|c|c|c|c|}
\hline Variables & [1] & [2] & [3] & [4] \\
\hline $\begin{array}{l}\text { Output Volatility } \\
\text { (S.D. annual log differences of G DP per capita) }\end{array}$ & $\begin{array}{l}-0.0873 * * \\
(0.023)\end{array}$ & $\begin{array}{l}-0.4213 * * \\
(0.158)\end{array}$ & $\begin{array}{l}-0.2376 * * \\
(0.087)\end{array}$ & $\begin{array}{r}-0.1285 \\
(0.104)\end{array}$ \\
\hline Output Volatility* Public Expenditure & .. & $\begin{array}{l}0.1055^{* *} \\
(0.053)\end{array}$ & $\begin{array}{l}0.0617 * * \\
(0.031)\end{array}$ & $\begin{array}{l}0.0224 \\
(0.037)\end{array}$ \\
\hline Output D rop & .. & .. & $\begin{array}{l}-0.8593 * * \\
(0.110)\end{array}$ &.. \\
\hline Output D rop * Public Expenditure & .. & .. & $\begin{array}{l}0.2810 * * \\
(0.038)\end{array}$ & .. \\
\hline Current D epth of Recession (CD R) & .. & .. &.. & $\begin{array}{l}-0.8213 * * \\
(0.122)\end{array}$ \\
\hline CD R * Public Expenditure & .. & .. & .. & $\begin{array}{l}0.2765 * * \\
(0.044)\end{array}$ \\
\hline \multicolumn{5}{|l|}{ Control V ariables } \\
\hline $\begin{array}{l}\text { Real Income Per Capita } \\
\text { (initial level of real G D P per capita, in logs) }\end{array}$ & $\begin{array}{l}1.0894 * * \\
(0.233)\end{array}$ & $\begin{array}{l}1.1339 * * \\
(0.193)\end{array}$ & $\begin{array}{l}1.0549 * * \\
(0.159)\end{array}$ & $\begin{array}{l}1.0662 * * \\
(0.155)\end{array}$ \\
\hline Real Income Per Capita squared & $\begin{array}{l}-0.0452 * * \\
(0.014)\end{array}$ & $\begin{array}{l}-0.0452 * * \\
(0.012)\end{array}$ & $\begin{array}{l}-0.0396 * * \\
(0.010)\end{array}$ & $\begin{array}{l}-0.0416 * * \\
(0.009)\end{array}$ \\
\hline $\begin{array}{l}\text { Inflation } \\
\text { (CPI inflation rate, in logs) }\end{array}$ & $\begin{array}{l}-0.1509 * * \\
(0.044)\end{array}$ & $\begin{array}{l}-0.1497 * * \\
(0.043)\end{array}$ & $\begin{array}{l}-0.1237 * * \\
(0.028)\end{array}$ & $\begin{array}{l}-0.1568 * * \\
(0.027)\end{array}$ \\
\hline $\begin{array}{l}\text { Public Expenditure } \\
\text { (C urrent G overnment E x penditure as \% G D P, logs) }\end{array}$ & $\begin{array}{l}-0.2847 * * \\
(0.075)\end{array}$ & $\begin{array}{l}-0.4089 * * \\
(0.106)\end{array}$ & $\begin{array}{l}-0.3748 * * \\
(0.061)\end{array}$ & $\begin{array}{l}-0.2746 * * \\
(0.062)\end{array}$ \\
\hline Countries / Observations & $72 / 470$ & $72 / 470$ & $72 / 470$ & $72 / 470$ \\
\hline \multicolumn{5}{|l|}{ Specification Tests (p-values) } \\
\hline - Sargan Test & $(0.321)$ & $(0.190)$ & $(0.482)$ & $(0.400)$ \\
\hline - 2nd. Order Correlation & $(0.286)$ & $(0.674)$ & $(0.210)$ & $(0.200)$ \\
\hline
\end{tabular}

$\mathrm{N}$ umbers in parenthesis are robust standard errors. Regressions indude constant and time dummies. ${ }^{*}\left({ }^{*}\right)$ denotes statistical significanœ at the 10 (5) percent level. 0 ur regression indudes the constant and time dummies (not shown above) and we compute small-sample bias corrected standard errors (W indmeijer, 2005).

1/ E x ternal instruments indude the volatility of terms of trade shocks, volatility of the growth of ex ternal demand and volatility of fluctuations in real international interest rates. 
Table 10

\section{Volatility and poverty}

Dependent Variable: Income growth for poorest quintile, Poverty G ap and Headcount Index at PPP \$1 a day (in percentages), end-of-period, in logs E stimation Method: G M M-IV System E stimator (A rellano and Bover, 1995; Blundell and Bond, 1998) with ex ternal instruments 1/

Sample of 48 C ountries, 1970-2005 (5-year period observations)

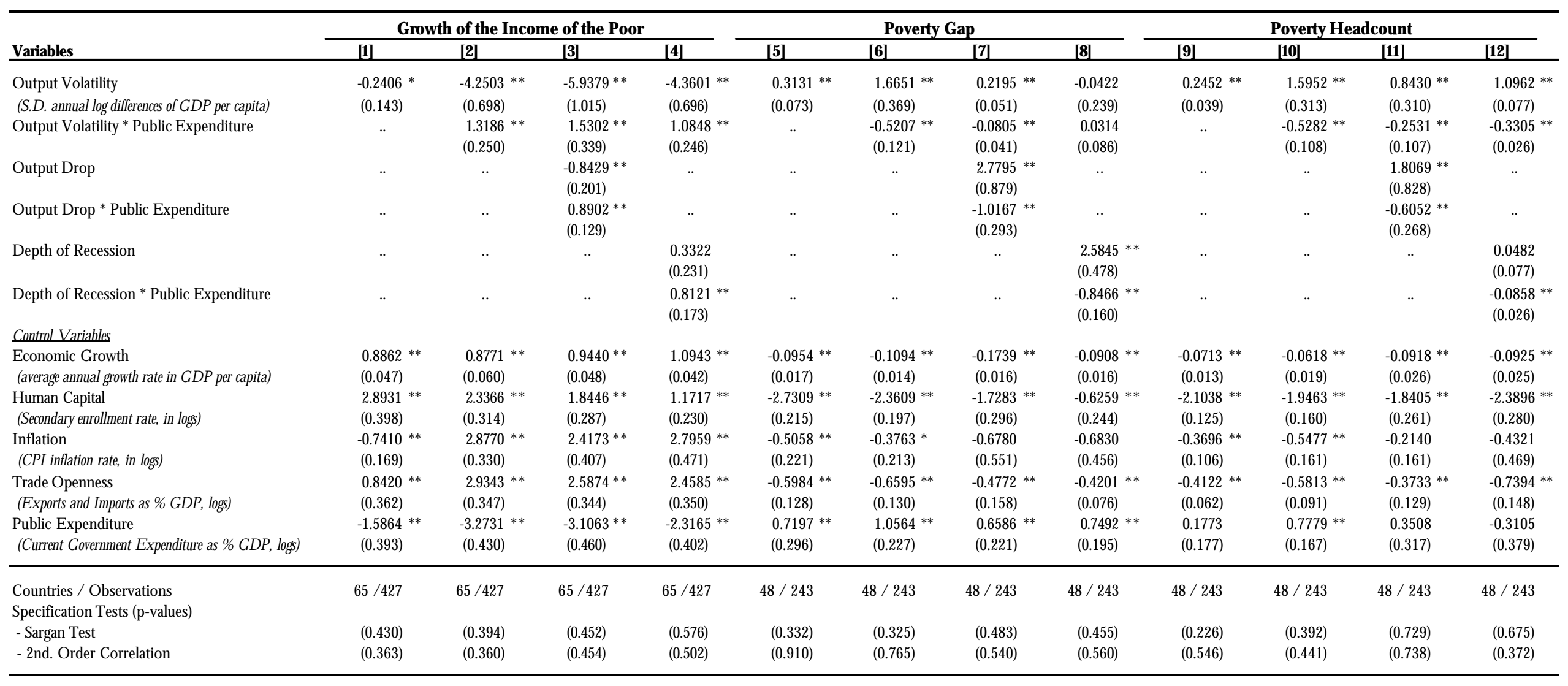

$\mathrm{N}$ umbers in parenthesis are robust standard errors. Regressions indude onstant and time dummies. * $\left.{ }^{* *}\right)$ denotes statistical significanoe at the $10(5)$ percent level. The standard errors are omputed using the small sample oorredion by W indmejer $(2005)$

1/ Ex ternal instruments indude the volatility of terms of trade shooks, volatility of the growth of ex ternal demand and volatility of fluctuations in real international interest rates. 


\section{Table A.1}

\section{Definitions and Sources of Variables Used in Regression Analysis}

\begin{tabular}{|c|c|c|}
\hline Variable & Definition and Construction & Source \\
\hline Gini Coefficient & Gini Coefficient of Income Inequality (0-100), end of period, and expressed in logs & $\begin{array}{l}\text { Authors' construction using Deininger and Squire (1996), } \\
\text { Milanovic (2000) and World Bank's World D evelopment } \\
\text { Indicators (WDI). }\end{array}$ \\
\hline Income Shares & $\begin{array}{l}\text { Income shares per quintile from the poorest (First) to the richest (Fifth), in } \\
\text { percentages (\%), end of period, and expressed in logs. }\end{array}$ & $\begin{array}{l}\text { Authors' construction using D eininger and Squire (1996), } \\
\text { Milanovic (2000) and World Bank's World D evelopment } \\
\text { Indicators. }\end{array}$ \\
\hline Poverty Gap & Poverty gap at \$1 a day (PPP), end-of-period, in percentages, and expressed in logs. & World Bank's World Development Indicators and POVCAL \\
\hline Poverty Headcount Index & $\begin{array}{l}\text { Poverty headcount ratio at } \$ 1 \text { a day (PPP), end of period, as percentage of } \\
\text { population, and expressed in logs. }\end{array}$ & World Bank's World Development Indicators and POVCAL \\
\hline Real Income per capita & $\begin{array}{l}\text { Ratio of real GDP (in US\$ at } 2000 \text { prices) to total population, beginning of period, } \\
\text { and expressed in logs. }\end{array}$ & $\begin{array}{l}\text { Authors' construction using Summers and Heston (1991) and The } \\
\text { World Bank's WD I. }\end{array}$ \\
\hline Economic Growth & Log difference of real GDP per capita. & $\begin{array}{l}\text { Authors' construction using Summers and Heston (1991) and The } \\
\text { World Bank's WDI. }\end{array}$ \\
\hline Human Capital & $\begin{array}{l}\text { Ratio of total secondary enrollment, regardless of age, to the population of the age } \\
\text { group that officially corresponds to that level of education. }\end{array}$ & Easterly and Sewadeh (2002) and The World Bank's WD I \\
\hline Inflation & $\begin{array}{l}\text { CPI inflation rate, in logs. It is computed as } \log ((1+d p) * 100), \text { where dp is the } \\
\text { inflation rate. This transformation smooths the original variable and gives less } \\
\text { weight to hyperinflation episodes. }\end{array}$ & $\begin{array}{l}\text { Author's calculations using data from IFS and the publications of } \\
\text { the Central Bank. The method of calculations is based on Beck, } \\
\text { Demiguc-Kunt and Levine (1999). }\end{array}$ \\
\hline Current Government Expenditure & $\begin{array}{l}\text { Current G overnment Expenditure as percentage of GDP, average of period, and } \\
\text { expressed in logs. }\end{array}$ & $\begin{array}{l}\text { The World Bank's World Development Indicators and IMF's } \\
\text { Government Financial Statistics }\end{array}$ \\
\hline & Log of the ratio of exports and imports (in 1995 US\$) to GDP (in 1995 US\$). & Easterly and Sewadeh (2002) and The World Bank (2003). \\
\hline Minimum Wages & $\begin{array}{l}\text { Ratio of minimum wages to labor cost per worker in manufacturing in current US } \\
\text { dollars per year. D ata on labor costs per worker are from plant-level surveys } \\
\text { covering relatively large firms, mostly in the formal sector of the economy. Figures } \\
\text { are converted into US dollars using the average exchange rate for each year. }\end{array}$ & Rama and Artecona (2002) \\
\hline Difficulty of Firing & $\begin{array}{l}\text { The difficulty of hiring index measures (i) whether fixed-term contracts are } \\
\text { prohibited for permanent tasks; (ii) the maximum cumulative duration of fixed- } \\
\text { term contracts; and (iii) the ratio of the minimum wage for a trainee or first-time } \\
\text { employee to the average value added per worker. This index takes values between } \\
0 \text { and 100, with higher values indicating higher ridigities. }\end{array}$ & Doing Business, Various issues \\
\hline Firing Costs & $\begin{array}{l}\text { The firing cost indicator measures the cost of advance notice requirements, } \\
\text { severance payments and penalties due when terminating a redundant worker, } \\
\text { expressed in weekly wages. If the firing cost adds up to } 8 \text { or fewer weeks of salary, } \\
\text { a score of } 0 \text { is assigned for the purposes of calculating the aggregate ease of doing } \\
\text { business ranking. If the cost adds up to more than } 8 \text { weeks of salary, the score is } \\
\text { the number of weeks. }\end{array}$ & Doing Business, Various issues \\
\hline Output Volatility & $\begin{array}{l}\text { Standard deviation in real output per capita, in logs --as in Fatas and Mihov (2006). } \\
\text { We compute the standard deviation of the cyclical component of output per capita } \\
\text { using the following filters: first differences, quadratic trend, and band-pass filter. }\end{array}$ & $\begin{array}{l}\text { Authors' construction using Summers and Heston (1991) and The } \\
\text { World Bank's WDI. }\end{array}$ \\
\hline Output D rop & $\begin{array}{l}\text { Dummy that takes the value of } 1 \text { when there is cumulative output loss larger than } \\
5 \% \text { of the pre-drop GDP within the period. }\end{array}$ & Authors' construction following Becker and Mauro (2006) \\
\hline Current D epth of Recession & $\begin{array}{l}\text { Dummy that takes the value of } 1 \text { whenever there is an output decline in excess of } \\
3 \% \text { of the pre-drop GDP within the period. }\end{array}$ & Authors' construction following Becker and Mauro (2006) \\
\hline Volatility of Terms of Trade Changes & Standard deviation of the annual log differences of the terms of trade index. & Authors' construction using The World Bank's WDI \\
\hline Volatility of Foreign Growth & $\begin{array}{l}\text { Standard deviation of the trade-weighted annual growth of the main trading } \\
\text { partners of the corresponding country. }\end{array}$ & $\begin{array}{l}\text { Authors' construction using Summers and Heston (1991), The } \\
\text { World Bank's WDI, and the IMF's D irection of Trade Statistics. }\end{array}$ \\
\hline Volatility of World Real Interest Rates & Standard deviation of the world real interest rate annual changes. & $\begin{array}{l}\text { Author's calculations with data from the IMF's International } \\
\text { Financial Statistics }\end{array}$ \\
\hline Period-specific Shifts & Time dummy variables. & Authors' construction. \\
\hline
\end{tabular}


Table A.2

Sample Statistics

Sample of 72 countries, 1970-2005 (5-year non-overlapping observations)

\begin{tabular}{lrrrr}
\hline & Average & Std. Dev. & Minimum & Maximum \\
\hline Inequality and Poverty (in logs) & & & & \\
Gini Coefficient & 3.67 & 0.23 & 3.09 & 4.15 \\
$\quad$ Income Share: First Q uartile & 1.73 & 0.38 & 0.40 & 2.39 \\
Income Share: Second Q uartile & 2.30 & 0.31 & 0.94 & 2.90 \\
Income Share: Third Quartile & 2.70 & 0.23 & 1.39 & 3.12 \\
Income Share: Fourth Quartile & 3.05 & 0.22 & 1.73 & 3.81 \\
Income Share: Fifth Quartile & 3.84 & 0.19 & 3.34 & 4.25 \\
Poverty Gap & 0.74 & 1.96 & -4.61 & 4.00 \\
Poverty Headcount & 2.02 & 1.69 & -3.00 & 4.49 \\
& & & & \\
Determinants (in logs) & & & & \\
Real Income per capita & 8.00 & 1.49 & 4.82 & 10.53 \\
Education & 3.89 & 0.68 & 1.49 & 4.99 \\
Inflation & 4.75 & 0.25 & 4.59 & 6.83 \\
Current G overnment Expenditure & 3.01 & 0.49 & 1.03 & 4.33 \\
Output Volatility & 0.73 & 0.73 & -1.35 & 2.69 \\
Trade Openness & 3.99 & 0.63 & 2.26 & 5.37 \\
\hline
\end{tabular}

